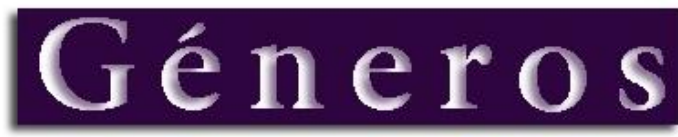

Multidisciplinary Journal on Gender Studies

\title{
Multidisciplinary Journal
}

\section{on Gender Studies}

\section{Volume 6, Number 1}

\section{Hipatia Press \\ www.hipatiapress.com}

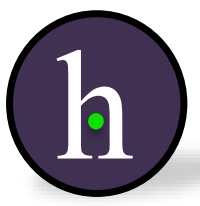

Undermining Dichotomies. Women and the Peace Process in Afghanistan.

Factors Associated with Domestic Violence against Rural Bangladeshi Women

Articles

Violencia de pareja contra las mujeres en México: una mirada a la atención del sector salud desde una perspectiva interseccional......1231

Employment, Motherhood and Wellbeing: A Discourse on the Trio within Public Organisations in Southwest Nigeria. 


\section{Géneros}

Multidisciplinary Journal of Gender: Studies

\section{Hipatia Press \\ www.hipatiapress.com}

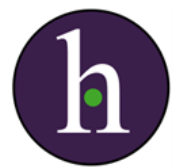

Instructions for authors, subscriptions and further details:

$\underline{\text { http://generos.hipatiapress.com }}$

\section{Undermining Dichotomies: Women and the Peace Process in Afghanistan}

Marissa Quie ${ }^{1}$

1) Department of Sociology, University of Cambridge, Cambridge, United Kingdom.

Date of publication: February $25^{\text {th }}, 2017$

Edition period: February - June 2017

To cite this article: Quie, M. (2017). Undermining Dichotomies. Women and the Peace Process in Afghanistan. Multidisciplinary Journal of Gender Studies, 6(1), 1187-1207. doi: 10.17583/generos.2017.2254

To link this article: http://dx.doi.org/10.17583/generos.2017.2254

\section{PLEASE SCROLL DOWN FOR ARTICLE}

The terms and conditions of use are related to the Open Journal System and

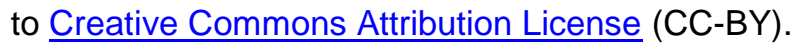




\section{Undermining Dichotomies: Women and the Peace Process in Afghanistan}

Marissa Quie

University of Cambridge

\section{Abstract}

This paper interrogates the equation of women and peace through the prism of the Afghanistan Peace and Reintegration Program (APRP). The Program was designed to create the conditions for inclusion of the insurgency within the democratic system and provide a roadmap for peace. It builds on a central justification of the war: the liberation of Afghan women. It requires gender mainstreaming in accordance with United Nations Security Council Resolution (UNSCR) 1325 and subsequent Resolutions, to include women in all stages of the process. The APRP underscores tensions between international and local standards that claim to ensure women's interests are protected in peacebuilding. The effort to impose gender mainstreaming is emblematic: yielding partial gains for women who have internalized international perspectives on their rights, but excluding those who have not.

Keywords: Afghanistan, APRP, peace, exclusion, marginalization, women 


\section{Dicotomías Debilitadoras: Mujeres y Proceso de Paz en Afganistán}

Marissa Quie

University of Cambridge

\section{Resumen}

Este documento interroga la ecuación de la mujer y la paz a través del prisma del Programa de Paz y Reintegración de Afganistán (APRP). El Programa fue diseñado para crear las condiciones para la inclusión de la insurgencia dentro del sistema democrático y proporcionar una hoja de ruta para la paz. Se basa en una justificación central de la guerra: la liberación de las mujeres afganas. Ello requiere la incorporación de la perspectiva de género de conformidad con la resolución 1325 del Consejo de Seguridad de las Naciones Unidas y las Resoluciones posteriores, para incluir a las mujeres en todas las etapas del proceso. La APRP subraya las tensiones entre los estándares internacionales y locales que pretenden asegurar que los intereses de las mujeres estén protegidos en la consolidación de la paz. El esfuerzo para imponer la incorporación de la perspectiva de género es emblemático: se obtienen beneficios parciales para las mujeres que han interiorizado las perspectivas internacionales sobre sus derechos, pero excluyendo a quienes no lo han hecho.

Palabras clave: Afghanistan, APRP, paz, exclusión, marginación, mujer 
I suffer not the work of any worker, male or female, to be lost (The Family of Imran, The Qur'an).

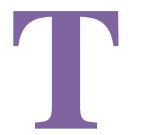

he Afghanistan Peace and Reintegration Program (APRP) was launched in 2010 to create the conditions for coexistence and dialogue with the Taliban. The Program builds on a central justification for the war: the liberation of Afghan women (Abu-Lughod, 2002).

Gender mainstreaming is a principal tenet of the process, stemming from ideas codified within United Nations Security Resolution (UNSCR) 1325 and subsequent Resolutions (1820, 1888, 1889, 1960, 2106, and 2122). These are targeted not only at the disproportionate impact of war on women, but also at the pivotal role women should and do play in conflict resolution and the realization of durable peace. The APRP underscores inevitable tensions between international and local standards that claim to ensure women's interests are protected in peacebuilding. The effort to impose gender mainstreaming is emblematic of this.

I argue that this effort has yielded partial gains for women who have internalized international perspectives on their rights, but excluded those who have not. Moreover, even those women who have benefited suffer from the paradox of being both seen and unseen. As standard bearers of what is often perceived as cultural imperialism, they are vulnerable to violent counterattack in the context of ongoing war.

The Women Peace and Security (WPS) agenda underpinning gender mainstreaming assumes symmetry in the positions of men and women: but fails to address the complex ways in which gender is perceived by power relations within particular societies. Considering men and women as though they confront similar obstacles reifies disparities between them. Formal numerical inclusion in the APRP, as in other political processes, has not and cannot ensure changed practices.

I want to interrogate what counts as participation. For women in rural communities, productive participation leads to a range of practical manifestations of agency in family and community life. It is a priority for women to realize peace and security, but different cultural requirements are needed for this. Participation has to be inclusive of difference. 
The discourse of the War on Terror concerning the "liberation of Afghan women" (Abu-Lughod, 2002) continues to contaminate the peace process and international attempts to ensure women's participation. There is a sharp focus on the gender apartheid of the Taliban, accompanied by neglect of more subtle forms of marginalization. While women's and human rights groups involved in the APRP have largely internalized Western narratives on gender equality, a range of alternative views exist. These groups cannot speak for all Afghan women. Marginalization or exclusion of women from post-conflict decisionmaking processes means that the specific issues surrounding women's vulnerability may not be adequately addressed, or even at all.

The Taliban were neither the architects of women's oppression in Afghanistan nor the only current source of their disempowerment. Feminist scholarship pays inadequate attention to the role of warlords in contemporary Afghan democracy and their ties with some women at the forefront of the peace process (Wordsworth, 2007, p. 3). These connections are overlaid by differences in ethnicity, tribe and class. Within the neat friend/enemy dichotomy, conflict-induced differences between women are overlooked.

Both the Afghan government and Taliban interlocutors to the peace process understand the value of the term 'gender' as a tool for legitimization and mechanism for external funding, which the APRP is entirely dependent upon (Quie, 2012). This at least ties the Program to rhetoric on gender mainstreaming. In reality, however, key protagonists are resistant to the very word 'gender.'

Afghans say that stories are the data of the soul. One that aptly captures the tensions surrounding the use of 'gender' in the APRP concerns a male colleague responsible for outreach to local women in Kandahar. A man fulfilled this role because of the intensity of conflict in the province. Women could not obtain security approval for the job. I asked him about his interactions with women and views on gender mainstreaming. He replied:

Gender is not a word I use in Kandahar. It is still confusing for us. People in local villages think it is a 'foreign invention.' They don't know what it means and neither do I. Instead, I translate it into our own language (Interview with Abdul Baser Miyakhil, 2010).

This anecdote highlights key problems I set out in this paper. Universal notions of freedom and participation encoded in the WPS agenda are not easily translatable in the Afghan context. The attempt to do this instead results in a loss of culturally relevant nuances surrounding local understandings of 


\section{Quie - Women and the Peace Process in Afghanistan}

these ideas. Potentially, this generates what, in the context of natural disasters, Harvey (2016) has termed as "secondary violences."

What happens when women's participation is mandated without a correlative effort to understand its complexities in an Afghan context? Why is there such a wide gap between the rhetoric and the realities of participation? Is all participation recognized, or do pre-conceived notions exclude those who fall outside these understandings? What is the significance of these exclusions? How does the dichotomization of gender and its link with peace and security undermine the potential for peace?

Although the media and international community depict the conflict through the bounded image of a friend/enemy distinction, it is far more complex. The former Gender Advisor to the APRP, Quhramaana Kakar, noted:

Now threats are everywhere. There is no clear enemy. At times, Taliban representatives to the peace process are more open to recognizing women than corrupt government officials. Even close family members can pose a threat to women's participation in conflict resolution and more fundamentally, to their safety (Interview, 2014).

Baryali Helali, a communications advisor to the peace process, said, "the peace program calls the Taliban 'brothers,' but we don't see them as an enemy to be destroyed (Interview, 2011).

The Taliban have never articulated a comprehensive political vision. On paper, they demand an Islamic Emirate based on a strict interpretation of Sharia - but this eschews gender equality as understood within the WPS framework. Further challenges are entailed by the tensions between Afghanistan's formal endorsement of UNSCR 1325 and subsequent Resolutions on the one hand and the primacy of Islamic law on the other.

Article 7 of the Constitution affirms that "Afghanistan shall observe the UN Charter, inter-state agreements and international treaties it has joined." Yet Article 3 states that "no law can be contrary to the beliefs and provisions of the sacred religion of Islam." This is reinforced by Article 130, which affirms that Hanafi law takes precedence when no provisions in the Constitution or other laws relate to specific cases (Afghanistan Online).

The tension between recognition of international human rights norms and Islam creates broad latitude for interpretation. A senior Taliban representative to the APRP, Mullah Hotak, acknowledged that the treatment of women under 
their regime had been "costly," and that they should be afforded "equal but different" recognition (Interview, 2010).

The notion of 'difference' is at odds with the WPS agenda; yet this term was prevalent among diverse actors in the peace process. The Deputy Minister to the APRP, Aziz Ahmadzai, cautioned against "one size fits all" attempts to empower women and involve them in conflict resolution: "Without cultural sensitivity and appreciation of difference, women will suffer more" (Interview, 2010). Women in conservative rural areas targeted by the APRP further highlighted the problem of 'difference': placing more emphasis upon influence within their families and communities than on individual rights.

The stress on 'difference' indicates that the WPS agenda does not seem to 'translate' well across differing cultural contexts. The prime focus of this research is therefore to explore the impact of gender mainstreaming on the Afghan peace process. This is critical in identifying obstacles to the implementation of UNSCR 1325 and subsequent Resolutions, and understanding how women's participation may be recognized and enhanced. It is a priority for women to realize peace and security; but different cultural requirements are required for this to be achieved.

UNSCR 1325 (2000) calls on member states to ensure the equal participation and full involvement of women in all efforts in peace and security promotion; and urges actors to incorporate a gender perspective. Subsequent Resolutions call for the further strengthening of women's participation in peace processes and the development of indicators to measure progress. Yet the Afghan peace process raises critical questions about what counts as participation, how it is manifested and ways in which it might be nurtured and developed.

Sixteen years after UNSCR 1325 was unanimously adopted, the conspicuous absence of women from peace negotiations underscores a disturbing gap between rhetoric and reality. A review of the APRP reveals that women have had little impact on the design or implementation of the process. In cases where women have been included, this has largely been an exercise of form over substance. Numerical inclusion cannot be equated with the notion of participation specified by the WPS agenda.

Within the family-centered and close knit rural communities of Afghanistan, women are conceptualized as the bearers of the family honour (haqq). Gender codes place the duty of protection on men. Women prove 


\section{Quie - Women and the Peace Process in Afghanistan}

themselves worthy of protection through adherence to strict moral norms, capacity for reproduction and roles as cares within the family. Transgression of gender codes routinely results in violence, including honor killings (Amnesty International, 2015).

Gender mainstreaming as practiced by the APRP brackets out masculinities; but this failure to address gender in a holistic way undermines the potential for attitudinal change. There are multiple forms of masculinity within Afghan communities, expressing both hierarchy and exclusion. Moreover, there is clearly a 'hegemonic' form of masculinity that ties in with patriarchy.

That said, men involved in the APRP often demonstrated a degree of ambivalence around masculinities. A Ministry official observed, "It is a problem that we don't allow our women to be educated. They are our servants but we are their servants" (Interview, 2010). The word 'gender' and the WPS agenda itself have come to be associated almost entirely with women. Yet men and boys are the gatekeepers of gender equality.

According to the sociologist, Raewyn Connell, "men predominate across the spectrum of violence" (Breines, Connell, \& Eide, 2000). She believes a strategy for peace must concern itself with this fact, the reasons for it, and its implications for violence. Masculinity is located within a structure of gender relations. Schwalbe (1992) argues that patriarchy - that is to say, the structure of gendered power - limits men's capacities to take the position of the 'other' and engage in an ethic of care.

This argument is highly relevant to the question of peace. Yet masculinity is not merely a static 'place' in a map of gender relations. Rather, it is an active social construction, a pattern of social conduct, which responds to the situations in which individuals find themselves.

The rhetoric of the War on Terror co-opted Western feminists: who viewed the intervention as a means of rescuing oppressed Afghan women. The pervasive epigram of the burqa depicts these women as shrouded by religion and patriarchy. Western media portrayals continue to recycle these images, obscuring cultural meanings and possibilities for agency. The positing of women's agency as co-substantial to relations of domination and the concomitant normalization of freedom/autonomy as an ideal is woven into the WPS agenda. 
Theorists such as Abu-Lughod (2002) offer a different reading. She refers to Papenak's description of the burqa as "portable seclusion." This presents adherence to cultural tradition (specifically, the veil) as signifying "belonging to a particular community and participating in a moral way of life in which families are paramount in the organization of communities and the home is associated with the sanctity of women" (Abu-Lughod, 2001).

Through their metamorphosis as subjects with duties and obligations into individuals with rights and freedoms, women participating in the APRP are not merely "free to choose" but obliged to be free, "to understand and enact their lives in terms of choice" (Rose, 1999, p. 87). Yet not only is this at variance with traditional conceptions of freedom within Afghan society; it is incompatible with what those women who have internalized Western discourses of rights want from the peace process. Within the critical reintegration phase of the APRP, these women opted for community-based recovery, repudiating ideas of individual rights and freedoms.

\section{Methodology}

This research aims to provide a context-based, qualitative analysis of the APRP through participatory observation and analysis of secondary sources. It derives from my role as a Consultant to the APRP between 2010 and 2016, focusing on the Ministry of Rural Rehabilitation and Development, the Ministry of Agriculture and the Ministry of Labor. My remit involved consultation with Afghan women, human rights groups, and other representatives of civil society. I also participated in consultations with the Taliban, alongside JS and International Security Assistance Force (ISAF) staff. As part of the implementation phase, I structured specialized development programs for former insurgents and ideas for de-radicalization centers.

Given the above, there is a risk of bias; but this is outweighed by access to highly sensitive sources: including reports on the emerging reintegration and reconciliation strategy, semi-structured interviews with Afghan and international stakeholders, primary documents connected with the APRP, media reports, recorded and unofficial conversations held in Kabul between April and November 2010, and correspondence or Skype interviews with Afghan leaders, carried out between November 2010 and July 2016. 


\section{Quie - Women and the Peace Process in Afghanistan}

Translators were used for interviews in Pashtu. This implies multiple possibilities for distortion; but every effort was made to verify the research presented. A context of extreme violence shaped the kinds of questions asked and information provided, mostly owing to the potential for the security of those interviewed to be compromised.

\section{Gendered Dichotomies}

Binary distinctions solidify the definition of women during the application of gender mainstreaming in the APRP. The central dichotomy of the WPS agenda is that of opposition between men and women in terms of war and peace. Harris and King (1989) argue that this distinction between aggressive, war-making men and nurturing, peaceful women is deeply problematic. Such myths tend to reinforce militarism, devalue women and de-legitimize multiple forms of agency deployed in the quest for peace.

The association between fighting and masculinity is clearly evident in the APRP. In June 2010, President Hamid Karzai convened The National Consultative Peace Jirga (NCPJ), in order to confer the Program with the seal of democratic legitimacy. From the outset, female representatives to the NCPJ expressed their sense of exclusion, referring to their "unique experience of war and deprivation and their emergence as survivors" (APRP, 2010).

Women's representatives drafted detailed proposals for applying United Nations Security Council Resolutions (UNSCR) 1325, 1820, 1888, 1889, 1960, 2106 and 2122; the 2004 Constitution (Afghanistan Online); and elements of the Afghanistan New Beginnings Program (UN Partnership for Peace), to include women in all stages of the process. They asked that a National Action Plan on Women, Peace and Security (Ministry of Foreign Affairs, 2015) be integrated as a core element of future national security policy. They sought a concrete process to encourage religious leaders to speak out on women's rights in Islam. They called for the APRP to promote access to education, health, justice, and other basic services; and improve awareness of women's rights through effective implementation (Nemat, 2011, pp. 32-9).

They also called for greater civic education, in order to raise awareness of women's rights at community level and improve support for female leadership in the peace process. They wanted independent monitoring of all government actions, particularly the peace process, as international forces withdrew. A 
majority supported gender mainstreaming throughout the APRP. Finally, they demanded a transparent system of monitoring/evaluation and a voice in the APRP Trust Fund, to ensure that financial incentives for reintegration were used to support women's empowerment and development and the protection of their rights (Interviews with members of the Afghanistan Independent Human Rights Commission (AIHRC) and the Afghan Women's Network, 2010-2014).

International donors to the Program insisted on recorded consultations with women and human rights groups - yet the ministry charged with design and implementation, the Joint Secretariat (JS), intentionally avoided this. The recommendations drawn up by women were not disseminated. Instead, both international and Afghan actors prioritized rapid implementation over a consultative design strategy. An international consultant noted, "Time is a luxury we don't have" (JS Meeting, June 2010).

Consequently, international actors only monitored the number of meetings that the JS held with women, rather than their qualitative impact. In correspondence, donors referred to the need for "cultural sensitivity" (Meetings with JS donors, June 2010). An international actor verbally advised of the need for "avoiding confrontation and any trace of cultural imperialism" (Ibid). JS officials, meanwhile, were savvy in their understanding of gender mainstreaming. They fulfilled the 'formal' requirement for women to participate in the process - but did not allow them a genuine voice.

This small snapshot illustrates the double marginalization which women activists experienced. Already excluded from the post-2001 political compact, they now found themselves marginalized by a charade of participation. The hidden rationale of JS officials is that "women don't participate in war and therefore have no real role in the pursuit of peace" (Interviews with JS officials, 2010-12), which echoes fundamental elements of international positions too.

The friend/enemy dichotomy has also resulted in further divisions which undermine the recognition of women's participation. In designing the process, ISAF pressed for 'de-radicalization': emphasizing the need for civic education to reintegrate former combatants. This was consistent with their understanding of the Taliban as an 'enemy.'

Women's and civil rights representatives concurred, believing it to be critical in transforming the consciousness of former fighters and their 


\section{Quie - Women and the Peace Process in Afghanistan}

communities, in order to cultivate a form of peace that reflected these rights (Interviews with female NCPJ representatives, 2010). Orzala Ashraf Nemat, a women's rights activist, asked, "What is the point of asking reintegrating combatants to accept the Constitution when they don't know what's in it?" (Interview, 2014) Nemat's question highlights the attention paid to rhetoric over practice.

Three ministries, including the Ministry of Hajj and Religious Affairs, were tasked with developing civic and vocational education. Yet leading JS officials rejected de-radicalization and were indifferent to civic education. They explained this was a response to what they considered an attack on "Afghan ownership." In reality, it may have owed to regular threats of violence from the Taliban.

The question of de-radicalization was particularly sensitive because it touched upon 'moderate' interpretations of Islam: which women and civil rights groups demanded as a vital component of the process. Senior JS officials argued that anything related to religion was off-limits for foreign actors, employing the rationale of "cultural sensitivity."

The eventual compromise was a much-diluted version of civic education, devised by ministries that demonstrated little enthusiasm for the APRP. Consequently, some ex-combatants undergo a weak type of de-radicalization, but most do not. This increases risks of recidivism and draws upon an exclusionary vision of peace and ownership. Conservative government actors were able to shrewdly exploit the idea of cultural imperialism. In the absence of a shared set of cultural meanings that facilitate intelligibility, women's voices were silenced.

Unlike South Africa, there are no Truth and Reconciliation Commissions in the Afghan peace process. Female representatives to the NCPJ asked for accountability for gender-based violence and other violations of women's rights and an end to impunity, particularly for sexual violence in war. They insisted on women's participation in transitional justice processes and the management of reparations. This demand continues to receive the backing of the Afghanistan Independent Human Rights Commission.

However, both the government and international actors focused merely on direct violence in war. 'Justice' is ostensibly achieved through what the ISAF Force Reintegration Cell (FRIC) refers to as "organic reconciliation" (Interview with Ileana Baca, 2011) within communities. This has been highly 
cost effective for international donors; but amounts to a capitulation to conservative Afghan factions, further constricting the space for genuine coexistence.

Fears that women's rights are being traded in exchange for reintegration and reconciliation with the Taliban were further underscored by the National Unity Government's recent pivot on the Constitution. President Ghani contends that a workable peace settlement will have to include a new Afghan Constitution, or institutional arrangements that allow the Taliban to become a legitimate part of the government (Haress, 2014).

This would provide for a loya jirga, in which representatives of the Taliban, the Afghan government, and civil society come together to amend the current Constitution or write an entirely new one. The price of peace for women who embrace the WPS agenda may therefore cost even more than war.

The pattern of form over substance is repeated in the representative dimension of the APRP. Both JS officials and Taliban interlocutors highlight what they perceive as the international community's "hypocrisy" in demanding 27\% female representation in Parliament and a significant position in the peace process by referring to the relatively low number of women in American and European political arenas. Some went further: warning of a "counterattack" on Afghan women involved.

Minister Stanekzai argued that measures to implement UNSCR 1325 under conditions of ongoing war and foreign occupation could be interpreted by Afghans as yet another form of colonial intervention. He referred to a "clash of civilizations" and the ways in which gender becomes a kind of "structuring principle" in contemporary debates between Western powers and Muslim countries. Against this background, opposition to mainstreaming women is tantamount to a reassertion of Afghan sovereignty (Interview, 2010).

The use of representation as a ruse for gender mainstreaming is also apparent within the showpiece leadership forum of the APRP. The HPC purportedly leads the peace and negotiation process. In reality, it does not play a central role in the effort to pursue negotiations with the Taliban. Under both President Ghani and his predecessor, Hamid Karzai, negotiations have largely taken place in secret.

Although nine of its 70 members are female, they cannot be said to provide a genuine voice for women. Female members of the Council whom I interviewed often spoke of being treated as "empty tokens" (Interviews, 2015- 
6). As in the Afghan Parliament, the presence of officials with known records of human rights abuses, war crimes and continuing links to illegal armed groups leads to a culture of fear and intimidation. This divides female members and renders them vulnerable to factional politics, ultimately silencing them.

Wordsworth (2007) maintains that contrary to the "romanticized portrayals in Western media," Afghan female politicians are divided "across ethnolinguistic, class, political and regional lines." Employing the concept of "multiple identities," she explains that women may have common interests, but other ties may be more significant. Women, like men, are also vulnerable to corruption.

In 2016, the Minister for Women's Affairs, Delbar Nazari, narrowly survived a vote of no confidence in Parliament. She was accused of corruption and professional ineffectiveness. The motion against Nazari illustrated the longstanding conflict between different female politicians for influence over the Ministry of Women's Affairs. War has fostered a culture of manipulation. The "patronage-based, zero-sum nature of Afghan politics contributes to a system where one person's gain is another's loss" (Ibid).

Moreover, secrecy and concealment are inherent in the operations of the APRP and silence women's voices. Although gender mainstreaming was mandated and a Gender Advisor appointed in 2010, the incorporation of women and recognition of their demands has been inconsistent. In July 2011, for example, 30 women from Hizb-i-Islami families approached Najira Zeweiri, a female representative on the HPC. Zeweiri put them in touch with the Gender Advisor, Kakar.

The women came to the JS at great risk, travelling from areas of intense conflict. Their message was clear: they were tired of war and the costs imposed on their families. They wanted their men to talk to the government: "We may not fight but we can influence our men." Yet they complained of "finding no space" for their voices within the process. They could not work and their children, particularly their daughters, could not pursue education. They wanted a genuine impact on the peace process and to set up a systematic program of talks (Interview, 2014).

Both the Head of the HPC, former President Rabanni (assassinated in 2011), and the Council were informed, but took no action. For them, participation in the conflict and its resolution was synonymous with combat 
and the decision to lay down arms. Kakar remarked that President Rabbani did not recognize the Hizb-i-Islami women's perceived influence within the family as action conducive to peace.

Interestingly, these women were themselves largely conservative and unlikely to have internalized Western ('foreign') narratives of women's rights. Recognition of their initiative may have legitimized calls by Afghan women's groups and international actors for a substantive role in the APRP. In an effort to placate Taliban participants (often rivals within the insurgency to Hizb-iIslami), however, the women's initiatives were sidelined. Their campaign was simply unacknowledged. This framing dichotomizes men as agents and women as passive pawns. Women were marginalized because they did not conform to constructed gender images (Elshatain, 1987, p. 4) of viable participation.

The same pattern can be observed in the trajectory of the NAPWA, a fundamental demand of female representatives to the NCPJ in 2010. More than five years later, it was finally launched by President Ghani - but appears to be yet another token designed in order to facilitate exclusion. No plan for implementation exists, no concrete set of responsibilities has been assigned to APRP institutions, and no timeline or budget has been proposed.

International donors are demanding remedies to these problems, and Ghani has assured women of full inclusion; but he will not "bother them until the right time" (Human Rights Watch, 2015). Women's activists interpret this as meaning that their participation is "an optional token" (Interviews with Wazima Frogh, 2015), rather than a critical component. Indeed, a 2014 report found that in 23 rounds of peace talks between the Afghan government and insurgency between 2005 and 2014, women were present on only two occasions (Oxfam, 2014).

The final phase of the APRP is perhaps most significant for the realization of women's participation, and is called "National Community Recovery." This is where reintegration of former combatants is achieved; but it disturbs fragile power balances. Women from Taliban families who may have suffered stigmatization often find themselves further punished. As the most powerless group within rural communities, they represent optimal targets.

Female fighters are virtually nonexistent in the Taliban. According to the JS, the number of female re-integree beneficiaries is so low, it could not be recorded. In deriving the equation between fighting and 'participation,' the 


\section{Quie - Women and the Peace Process in Afghanistan}

APRP does not recognize the indirect support women provided to the insurgency (Interview, 2010). Instead, women are conceptualized as inseparable from the family unit. This is highly problematic: although women do not carry weapons, they play critical roles in providing moral and logistical support to fighters. Reintegration/reconciliation is simply assumed through communities' acceptance of ex-combatants; but women enjoy no entitlements linked to their individual rights.

Their views are actually substantially at odds with the perspectives of international and Afghan government actors, but this is ignored. Gender mainstreaming only applies to women who champion "universal" principles of peace and security. This has serious implications for transnational feminist praxis, efforts to construct counter-hegemonic projects and transform dominant structures of power that give rise to war. It points to a real, pressing need to incorporate difference.

\section{Discussion}

Efforts to mainstream UNSCR 1325 into the APRP raise fundamental questions about how policy concepts are translated into practice. Evaluation of successful practice touches on interpretations of the meanings of equality, freedom and active agency. Much of the effort to 'translate' the WPS agenda is founded on un-nuanced dichotomies. A language of rights cannot fully capture the complications of lives actually lived. A vision of freedom as autonomy/freedom to choose is linked to participation: silencing action that falls outside these boundaries.

As Charlesworth and Chinkin (2002) note, the trouble with: "All types of gendered discourse is that it makes some courses of action impossible to contemplate... gendered discourses and thinking in dichotomies confines our perspective to simple either-or propositions."

Moreover, women's empowerment is perceived as a threat to Afghan culture and traditional values. Stanekzai advised that this framing could exacerbate violence: "Attitudinal change is critical." To remedy this, he suggested bringing concepts of male and female rights into public spaces through locally valued community practices (Interview, 2014).

Gendered discourse of 'rescue,' integral to legitimization of the War on Terror, also seeps into the APRP. The difficulty lies in the destination this 
implies. Postcolonial scholars emphasize that the idea of 'rescue' tends to be based on an equality norm modeled on Western liberalism (Abu-Lughod, 2002). In Foucauldian terms, liberal equality norms are naturalized within the WPS agenda. Alternative forms of freedom rooted within webs of legitimacy outside the borders of individual agency are overlooked or even excluded altogether.

The dichotomy of men as warriors and women as peacemakers obscures the extent to which women participants are affected by class-based, ethnic and tribal differences, all of which impact on capacities for agency. Afghanistan is a multi-ethnic society, where ethnic ties seem in most cases to trump gender-based solidarity.

Stanekzai drew attention to the paradox of "wanting to overcome invisibility while risking the dangers of being seen" (Interview, 2012). Wazima Frogh, co-founder of the Women Peace and Security Research Institute, reaffirmed the issue of risk: "We used to engage with lots of reintegrated Taliban but then many of the women were warned, some were attacked and injured and therefore we stopped." She has received multiple threats of violence because of her involvement in the APRP: "Telephone and face-to-face threats. People came to my house warning my father to stop his daughter from defaming and dishonoring him" (Interview, 2015).

The recent occupation of Kunduz substantiated the fear of violent consequences. In a systematic campaign, the Taliban ruthlessly pursued women in public roles, particularly activists for peace and democracy. Messages were left with their neighbors saying: "Return and you will be dead" (Interview, 2015).

This has been particularly terrifying for women because of Kunduz' violent past, including at least two cases of stoning (Nordland, 2010). It has taken years for women to feel secure enough to embrace public roles; now, they are targeted again. Omnipresent fear means that few will feel able to defend their positions in the peace process as it moves forward.

Important Afghan power asymmetries have also been concealed. The National Unity Government contains powerful warlords: including Abdul Rashid Dostum, the Vice-President. A number of women in positions of power have close ties with warlords. Ramazan Bashardost, a former candidate for the presidency, notes that much of the HPC "has more experience of war than of peace;" and that it is difficult to promote the WPS agenda through 
open debate when significant actors have access to substantial militias and do not hesitate to abuse their power (Interview, 2016).

Similarly, Azarabaijani-Moghaddadam (2007) contends that "women and the institutions set to protect and further their rights know that they are fair game if they cross the line and challenge conservative elements - knowledge that keeps them in a state of paralysis."

\section{Conclusion}

The lacunae between the rhetoric and realities of women's participation illuminate clear failures of the WPS strategy in recognizing multiple identities and subtle expressions of agency. Sustainable peace is an intersubjective phenomenon. The APRP has an inadequate focus on how peace is shaped by discourses and practices. It mistakenly assumes that its overall purpose is so apparent that examination or a genuinely broad dialog is not required. Lack of clear mechanisms for or recognition of dialog, as in the neglect of the Hizb-iIslami women's initiative, militates against a new consensus.

A central way in which feminism and crisis thinking may intertwine is when feminist ideas are co-opted to legitimize crisis interventions. International actors in the APRP, particularly women, believed they were working to improve the situation of all Afghan women. They were unaware or unconcerned about the suppression of those who did not share their vision of peace.

International actors, meanwhile, certainly did not anticipate that their participation in the APRP would bolster conservative positions on Sharia law and undermine the quest for women's rights, but their goal of a rapid exit stifled other aims. They employed the ruse of "cultural sensitivity" to conceal their interests. Clearly, feminist ideas serve diverse, often unintended purposes.

The goal of the APRP is to create the conditions for an inclusive peace by enfranchising the Taliban and other marginalized groups. Gender mainstreaming is intended to promote and enhance women's participation in all aspects of conflict prevention, management and resolution. However, a uni-dimensional understanding of gender that brackets out those women who have not internalized international norms fails to build the capacities of all 
women to engage in the peace process. This dichotomization of the universal and the local has proven highly counterproductive.

Heyzer warns that "we must guard against regarding gender equality and women's empowerment as a set of technical tools and concepts de-linked from practices, power and politics" (2005, p. 11). Overcoming dualities implies wider empowerment. If empowered communities are the site of transformative agency, the most expansive possible understanding of gender must be deployed. Ethics of care stand in sharp contrast to the artificiality of the application of universal standards.

Gilligan regards this uniform application as "morally problematic, since it breeds moral blindness of indifference" (2008, p. 471). Through the lens of the ethics of care, individuals have varying degrees of dependence and interdependence on one another. This differs from deontological and consequentialist perspectives, which tend to view them as having independent interests and interactions.

The gender dualism of the WPS agenda places men and women in contradiction with each other. The Taliban portray themselves as the protectors of Afghan culture and the purity of its women. This delineates an opposition: identifying with the West means rejecting Afghan heritage; while rejecting the West means clinging to tradition and accepting subordination. As Weeda Mehran, a women's rights activist, put it, "the solution is to pursue peace in ways that overcome the divide" (Interview, 2015).

\section{References}

Abu-Lughod, L. (2002). Do Muslim women really need saving?

Anthropological reflections on cultural relativism and its others.

American Anthropologist 104(3), 783-90. Available:

http://org.uib.no/smi/seminars/Pensum/Abu-Lughod.pdf

Afghanistan Online. The constitution of Afghanistan. Available:

http://www.afghan-web.com/politics/current_constitution.html

APRP. (2010). The Afghanistan Peace and Reintegration Program (APRP)

Executive Summary. Available:

https://ronna.apan.org/FRIC/APRP\%20Policy\%20Documents\%20Structu res $\% 20$ and $\% 20$ SOPs/APRP $\% 20$ Executive $\% 20$ Summary $\% 20-\% 20$ Final \%2012\%20July.pdf 
Amnesty International. (2015). Their lives on the line: Women human rights defenders under attack in Afghanistan. Available:

http://www.wluml.org/sites/wluml.org/files/ASA1112792015ENGLISH. pdf

Azarabaijani-Moghaddam, S. (2007). On living with negative peace and a half-built state: Gender and human rights. International Peacekeeping 14(1), 127-42.

Breines, I., Connell, R., \& Eide, I. (Eds.). (2000). Male roles, masculinities and violence: A culture of peace perspective. UNESCO. Available: http://unesdoc.unesco.org/images/0012/001206/120683E.pdf

Charlesworth, H., \& Chinkin, C. (2002). The boundaries of international law: A feminist analysis. Manchester: Manchester University Press. Elshatain, J. B. (1987). Women and war. Chicago: University of Chicago Press

Gilligan, C. (2008). Moral orientation and moral development. In A. Bailey \& C. J. Cuomo, The feminist philosophy reader. Boston: McGraw-Hill. Haress, G. (2014). Did politics compromise Afghanistan's constitution? Foreign Policy, October 23. Available: http://foreignpolicy.com/2014/10/23/did-politics-compromiseafghanistans-constitution/

Harris, A., \& King, Y. (Eds). (1989) Rocking the ship of state: Toward a feminist peace politics. Boulder, CO: Westview Press.

Harvey, D. C. (2016). Social policy as secondary violences in the aftermath of a disaster. Humanity and Society, February 23, 2016. Available: http://has.sagepub.com/content/early/2016/02/22/0160597616632803.abs tract

Heyzer, N. (2005). Making the links: women's rights and empowerment are key to achieving the Millennium Development Goals. In C. Sweetman (Ed.), Gender and the Millennium Development Goals. Oxford: Oxfam. Human Rights Watch. (2015). Afghanistan: Accept Full Role for Women in Talks. September 27. Available:

https://www.hrw.org/news/2015/09/27/afghanistan-accept-full-rolewomen-talks

Ministry of Foreign Affairs. (2015). Afghanistan's National Action Plan on UNSCR 1325 - Women, peace and security. Available: 
https://unama.unmissions.org/sites/default/files/wpsafghanistan national action plan 1325 0.pdf

Nemat, O. A. (2011). Afghan women at the crossroads: Agents of peace - or its victims? Available: https://tcf.org/assets/downloads/tcfafghanwomen_\%281\%29.pdf

Nordland, R. (2010). In bold display, Taliban order stoning deaths. The New York Times, August 16. Available: http://www.nytimes.com/2010/08/17/world/asia/17stoning.html? r $=2$

Oxfam. (2014). Behind closed doors: The risk of denying women a voice in determining Afghanistan's future. November. Available: https://www.oxfam.org/sites/www.oxfam.org/files/file_attachments/bp20 0-behind-doors-afghan-women-rights-241114-en.pdf

Quie, M. (2012). Peace-building and democracy promotion in Afghanistan: the Afghanistan Peace and Reintegration Program and reconciliation with the Taliban. Democratization 19(3), 553-74. Available: http://www.tandfonline.com/doi/abs/10.1080/13510347.2012.674362 Rose, N. (1999). Powers of freedom: Reframing political thought. Cambridge: Cambridge University Press.

Schwalbe, M. (1992). Male supremacy and the narrowing of the moral self. Berkeley Journal of Sociology 37, 29-54.

UN Partnership for Peace. Afghanistan's new beginnings program. Available: https://www.yumpu.com/en/document/view/42065012/afghanistans-newbeginnings-programme-cmi

United Nations Peacekeeping. Women, peace and security. Available: http://www.un.org/en/peacekeeping/issues/women/wps.shtml Wordsworth, A. (2007). A matter of interests: gender and the politics of presence in Afghanistan's Wolsei Jirga. Kabul: AREU. 
1207 Quie - Women and the Peace Process in Afghanistan

Marissa Quie Research Associate in the Department of Sociology, Faculty of Human, Social and Political Science, at University of Cambridge.

Contact address: Department of Sociology, Free School Lane, Cambridge CB2 3RQ, United Kingdom.

E-mail address: Mq10000@cam.ac.uk 


\section{Géneros}

Multidisciplinary Journal of Gender: Studies

\section{Hipatia Press \\ www.hipatiapress.com}

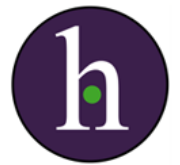

Instructions for authors, subscriptions and further details:

http://generos.hipatiapress.com

\section{Factors Associated with Domestic Violence against Rural Bangladeshi Women}

Anisur Rahman Khan ${ }^{1}$

1) Department of Social Relations, East West University, Bangladesh.

Date of publication: February $25^{\text {th }}, 2017$

Edition period: February - June 2017

To cite this article: Khan, A. R. (2017). Factors Associated with Domestic Violence against Rural Bangladeshi Women. Multidisciplinary Journal of Gender Studies, 6(1), 1208-1230. doi: 10.17583/generos.2017.2085

To link this article: http://dx.doi.org/10.17583/generos.2017.2085

\section{PLEASE SCROLL DOWN FOR ARTICLE}

The terms and conditions of use are related to the Open Journal System and

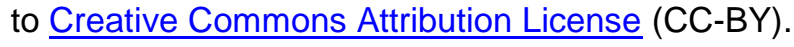




\section{Factors Associated with \\ Domestic Violence against \\ Rural Bangladeshi Women}

Anisur Rahman Khan

East West University

\section{Abstract}

This study examines the causes of domestic violence against rural Bangladeshi women. By drawing on thirty-nine semi-structured in-depth interviews through phenomenological approach of qualitative study, conducted in eight rural settings in Netrokona and Mymensingh districts, it was found that every experience of the women with domestic violence has a context or contexts. Broadly, the prominent causes of domestic violence were identified as dowry-demand, polygamy and extramarital relations, in-laws syndrome, childless and sonless state, questioning husbands, and not meeting the husbands' and in-laws' expectations. Patriarchal structure and system of the society are broadly and dominantly interwoven in every factor of domestic violence. Making structural changes to women's subordination is the most important strategic response to eliminate or prevent domestic violence from the society.

Keywords: Bangladesh, domestic violence against women, factors, patriarchy, women's subordination 


\title{
Factores Asociados a la Violencia Doméstica contra las Mujeres Rurales Bangladesís
}

\author{
Anisur Rahman Khan \\ East West University
}

\section{Resumen}

Este estudio examina las causas de la violencia doméstica contra las mujeres rurales de Bangladesh. A partir de treinta y nueve entrevistas semi-estructuradas a través del enfoque fenomenológico del estudio cualitativo, realizado en ocho contextos rurales de los distritos de Netrokona y Mymensingh, se encontró que cada experiencia de violencia doméstica tiene un contexto o contextos. En términos generales, las causas prominentes de la violencia doméstica se identificaron como la demanda de dote, la poligamia y las relaciones extramatrimoniales, el síndrome de los cónyuges, no tener hijos, el cuestionamiento del marido y no cumplir con las expectativas de los maridos y las leyes. La estructura patriarcal y el sistema de la sociedad están ampliamente y predominantemente entretejidos en cada factor de violencia doméstica. Hacer cambios estructurales a la subordinación de las mujeres es la respuesta estratégica más importante para eliminar o prevenir la violencia doméstica de la sociedad.

Palabras clave: Bangladesh, violencia domestica contra las mujeres, factores, patriarcado, subordinación de las mujeres 


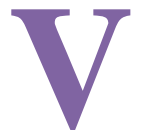

iolence against women is a pervasive form of abuse which has spread over the entire world irrespective of cultural, geographic, social, or economic demarcations (Naved and Persson, 2005). It is so widely and commonly spread irrespective of country and society that it is considered by some experts as normal (Levy, 2008). It is like a global epidemic which serves as a tool of the violation of human rights (Amnesty International, 2004). On the other hand, domestic violence consists of physical, sexual, psychological and controlling behaviour against an intimate partner (Esquivel-Santoveña, Lambert and Hamel, 2013). Very specifically, domestic violence or violence that takes place at home accounts for a major portion of the violence that occurs worldwide against women (Perillia, Lippy, Rosales, and Serrata, 2011). Specifically, domestic violence which is perpetrated by the husband cuts across socio-economic, religious, and ethnic boarders (Richardson, Coid, Petruckevitch, Chung, Moorey, and Feder, 2002). It is a dangerous practice and it is often said that the safest palace for men is the home; alternatively, the home is the least safe place for women (Edwards, 1989). Research indicates that domestic violence is the most pervasive and widespread problem around the world (Esquivel-Santoveña, Lambert and Hamel, 2013). It is generally estimated that one in four women in their lifetime and between one in ten women experience violence annually (Women's Aid, 2009). Millions of women are injured and thousands are killed each year as a result of domestic violence (Hattery, 2009). Although various forms of violence are perpetrated against women, the state of domestic violence perpetrated by husbands is very serious in Bangladesh. It is often treated as a part of the normative order in social relations and only comes to light if it results in serious injury. In fact, many women tend to accept it as a reality of their life (Siddiqi, 2006). Such violence is one of the most extorting cultural practices in all times in Bangladesh (Bhuiya, Sharmin, and Hanifi, 2003). As a public policy problem, the government of Bangladesh has made strides in harmonising the national legislation with international commitments to protecting the rights of women and eliminating violence against them (Johnston and Naved, 2008). Despite having interventions from the government for the protection of women in Bangladesh, domestic violence is continuing and in some cases increasing day by day (Khatun and Rahman, 2012). Different available empirical studies in Bangladesh reported high rates 
of various forms of wife abuse ranging from 39 percent to 79 percent (Schular, Hashemi, Riley, and Akhter, 1996; Koenig, Ahmed, Hossain, and Khorshed, 2003; Bates, Schular, Islam, and Islam, 2004; Salam, Alim and Noguchi, 2006; Naved, 2013). However, empirical works on domestic violence against women in the context of Bangladesh are not only limited, but most of the available works are based on positivist approach which makes it difficult to grasp in-depth, thick and inclusive picture of domestic violence. In fact, quantitative methods and survey approaches, in particular, are not sensitive to women's experiences and concerns (Skinner, Hester, and Malos, 2005). Moreover, the dearth of subjective understanding of various causes of domestic violence is one of the major gaps of the existing literature. Notably, a vital part of preventing a social problem is to have an understanding of what causes it (Crowell and Burges, 1996). In this research, I have made an attempt to explore the causes or the contexts of domestic violence against rural Bangladeshi women perpetrated by their husbands.

\section{Research Design}

This paper is an outcome of a broader study conducted through an interpretive qualitative research approach in rural Bangladesh. An interpretive approach assumes that there is not just one empirical world, but everyone has their own personal views and perspectives of reality (Thiel, 2014). It typically tries to understand the social world from the perspective of individual experiences (Rossman and Rallis, 2012). Under this framework, individuals develop subjective meanings of their experiences leading the researcher to look for complex understanding rather than narrower meanings (Creswell, 2013). Any site in Bangladesh is a suitable setting for studying domestic violence for its high level of prevalence. This study was conducted in eight rural settings of Mymensingh and Netrokona administrative in Bangladesh. A majority of Bangladeshis (seventy-seven percent) live in rural areas (BBS, 2012). No study on domestic violence has ever been conducted in these districts, which was the prime motivation for doing so. Although sample size is not essential in qualitative research, it is generally important to have a reasonably good size, in order to obtain meaningful understanding from the data and its analysis (Onwuegbuzie and Leech, 2005 quoted in Tonsing, 2014). Moreover, the act of focusing sampling in qualitative research should be as strategic as it is 
practical (Mason, 2002). Keeping this in view, I selected thirty-nine victims of domestic violence, who were currently in or had been in abusive intimate relationships. In making this selection, great emphasis was placed on participants who were 'information-rich' (Hennink, Hutter, and Bailey, 2011) and therefore both purposive and snowball sampling techniques were employed in selecting them. I selected them through an array of networks: relatives, friends, government officials, NGO officials, community people, and the victims themselves who helped to select respondents. The study was conducted between August and November 2014.

The socio-demographic characteristics of the participants revealed that the average age of was twenty-eight, ranging from seventeen to fifty. The majority of the participants were from Bengali Muslim community (thirtythree), followed by Bengali Hindus (four) and the indigenous matriarchal Garo community (two). In terms of their marital status, the majority of the participants were deserted by their husbands (fourteen), separated according to their own wish (nine), living with husbands (eight), divorced (three), and husband living abroad (one). Moreover, four participants had two different types of relationship status because of being married twice. One participant was divorced by her first husband and deserted by the second husband, one was divorced by the first husband and later separated from second husband according to her wishes, one became widowed, and got married again, but was divorced, and one became widowed and was deserted by the second husband. Besides the participants that were formally divorced, the rest of them still had marital relations with their husbands on paper irrespective of their current living status.

Six were full-time salaried employees, twelve were self-employed in small businesses, and the rest were completely dependent for their livelihoods either on their husbands or other family members such as parents, brothers or sons. With regard to educational status, ten participants were illiterate, and ten literate. Only one participant had completed graduation and one had a postgraduate degree. Three participants had passed the higher secondary school examination, two participants had passed the secondary school examination, and three participants had passed the primary school examination. On the other hand, three participants had studied up to the secondary level but could not complete it, and six participants had studied up to the primary level but could not complete it. Most of the participants were married before their 


\section{Khan - Violence Against Rural Bangladeshi Women}

eighteenth birthday, which is the minimum legal age to marry for women in Bangladesh. On average, each woman had two children.

While interviewing women victims of domestic violence I was concerned about being a male researcher since disclosure about violence may be affected by many factors including the gender of the interviewer (Ellsberg, Heise, Peña, Agurto, and Winkvist, 2001). I was more careful about gaining the trust of my participants through building appropriate rapport. I developed rapport before each interview so that the barrier between the male researcher and female participant was minimised as much as possible. In all cases, I had many informal discussions with the participants and that helped to gain their trust quickly. I must admit that in some cases, I had some difficulties making them open-up to my expectations, but with my utmost efforts I could overcome most of the difficulties, and took great delight in every interview. Informed consent was obtained from all and, in accordance with the World Health Organization (WHO, 2001) guidelines, maintaining the privacy and safety of the respondents was the primary concern. Interviews were conducted, exclusively based on the choice of place and time of the respondents. Only pseudonyms were used in the reporting formats. Participation in the study was voluntary and all interviews were conducted in the local language, Bangla, and were recorded with the prior permission of the respondents. While translating into English, I was careful to record each narrative verbatim so that originality was maintained and errors remained to a minimum.

I used the thematic analytical technique in presenting the findings of the data. Specifically, the thematic analytical framework identifies and analyses themes and puts them together to form a comprehensive picture of the collective experiences of research participants (Braun and Clarke, 2006). Notably, there is no specific rule on how to develop themes, as themes can also be developed on relatively little of the data set (Braun and Clarke, 2006). I conducted the entire research process through interactive means and as such, was familiar with the data and had some initial thoughts as well in framing the themes. Audio-recorded interviews were transcribed verbatim by me. Thematic analysis demands close reading of the interviews. Although it was a laborious process, it gave me a firm grip of the data. I concentrated slowly and line by line on the transcribed conversations or interviews, and carefully identified the regular-recurring experiences, perceptions, and feelings of the 
research participants. I grouped all of the similar patterns or categories together, and picked them as "themes." The data analysis observed the following sequential but interrelated procedures: organizing data, generating categories, coding, collating codes into potential themes, defining and refining themes, and finally presenting the overall story of the different themes revealed (Marshall and Rossman, 1999). The textual presentation of the finding is done in first person "I" which articulates attention to my authorship and expresses my reflexivity and involvement as researcher.

\section{Factors of Domestic Violence}

I identified the following major factors which are very closely connected with domestic violence against rural Bangladeshi women.

\section{Dowry Demand}

The demand for a dowry was the most common factor in the perpetuation of domestic violence, and it is rooted in the social acceptance of the practice. Everybody knows that a dowry is a necessary and unavoidable condition if the parents want to get their daughters married. The majority of the women in the study reported that they were abused in a number of ways due to the demand for a dowry. The following excerpt is very significant in terms of contextualising this problem.

If Allah (God) would make a money-plant and if my husband would pluck money from it, he would be the happiest man in the world (Jhorna).

Some victims were often sent back to their family of origin following physical or mental abuse due to a dowry demand and could only go back by bringing a dowry. Some victims were either permanently sent back or forced to return to the home of origin due to excessive demand for a dowry. For some husbands, the demand for a dowry was a routine activity. They always forced their wives to bring a dowry from their parents. If they failed, they abused their wives to the extreme. Two excerpts are as follows: 


\section{Khan - Violence Against Rural Bangladeshi Women}

When I could bring money from my brothers, he was happy. If finished, he again forced me to bring money (Sharifa).

One day my in-laws call my father, and told him to take me back. The reason was they demanded huge sums of money, which my father was unable to pay at that moment. They said send your daughter back if you can meet the demands (Seuti).

On the other hand, one of the reasons for Joita being divorced was a dowry demand. Her father failed to meet the demands of her husband and in-laws. Moreover, threatening the wife with divorce was a common weapon unless the demand a for dowry was met. Many women experienced serious physical violence due to the demand for a dowry. For example, Bristi was one of the few victims against whom finally a murder was attempted. It was because of the fact her father could not pay the demanded amount of the dowry. Bristi shared that her husband began the dreadful scene in the following way:

You have brought 100000 taka and stayed more than three years. It is more than enough. You could not bring the rest, so you must vanish. I will marry again and get more money (Bristi).

Similarly, Renu also thought that one of two main reasons (another one was extramarital relations) for attempting to murder her was the demand for 500000 taka as a dowry by her husband. Her case was interesting. Her husband did not demand any dowry during marriage. After having been engaged in an extramarital affair with his student he started demanding a dowry and abused her on those grounds so that Renu would leave him permanently. Shirin, on the other hand, had to flee from her husband's home failing to cope with the dowry demand, as she indicated in the following:

The intensity of his physical violence for demand for dowry was escalating, and he was even threatening me to kill. I thought the way he is moving at any time he might kill me. So, one morning, I fled from home (Shirin).

Soma's husband hit her leg severely with an iron rod since she failed to bring a dowry as per her husband's expectation. He also threatened her in the following rough way: 
If you find "husband" is tasty, then in order to have this taste you must buy it by fetching enough money from your father. If you fail, I would stitch your mouth for ever (Soma).

According to Hindu custom many dowries are paid to the groom during marriage, even though some Hindu participants said that the demand for a dowry of their husbands continued even after marriage. For example, during marriage, Shelekha's mother gave money to her husband and registered a piece of land in the name of Shelekha. Nevertheless, her husband abused her in many ways so that Shulekha transferred that land to her husband. Shelekha thought that one of the reasons for the disappearance of her husband was due to the fact that she did not transfer the land to his name. There were many examples in the study concerning the demand for a dowry which acted as a factor in domestic violence.

\section{Polygamy and Extramarital Relations}

"Women against women" in many ways acted as a source of domestic violence. Some participants were the victims of husbands' practices of polygamy and extramarital relations. However, these two practices were invariably linked with all of the forms of violence. In the following, I specifically present a few of the women's experiences of domestic violence caused by polygamy or extramarital relations.

The existence of another woman in Suchanda's husband's life devastated her. She got married to Shukumar in 1996. Suddenly in 2012, her husband developed a relationship with a Garo woman. On the matter of this relationship, there were many conflicts between them. Finally, he eloped with the woman. Her husband abused her in many ways. Her shop and its materials were destructed, she was deliberately sexually deprived and she was even beaten cruelly in front of many people in the market area. Amena was married in 1984. Her husband became engaged in extramarital relations with a few women after 1997. Finally, in 2007, he married a woman of her eldest daughter's age. Amena was also severely abused in many ways by her husband on the matters of conflict concerning her husband's extramarital relations and marriage. She even had to stay as a co-wife in the same house, which further brought a tremendous emotional pressure upon her. Rokeya's 


\section{Khan - Violence Against Rural Bangladeshi Women}

husband got married to another woman. When Rokeya's husband came back home permanently with his new wife, Rokeya had no option but to stay with them in the same residence. Several times her husband abused her on matters of that relationship. She remarked: "My husband said if I marry what is wrong with you? There is no harm if a man marries more than one (Rokeya)".

Molly and Bobby, two Garo women in the study, were also the victims of the husbands' extramarital affairs at some point of time. Once having had an affair with other women, their husbands abused them in many ways. Both Jinat and Shoheli came back to their family of origin with their children once their husbands got married again. Afterwards, their attempts to enter into their husbands' residences were foiled by both their husbands and their new wives. This clearly shows that nothing but polygamy kept them from attaining their own rights and the rights of their children. Hena, on the other hand, got married to a widower after being divorced by her husband. However, within a year, her new husband married three more times. She was also abused in many ways. Finally, he expelled Hena from the home. Hena remarked: "This man says that he does not keep a wife for more than a year (Hena)".

Rasu's husband maintained an illicit relationship with one of his female students. On the matter of that relationship, Rasu's husband abused her in many forms. He even seriously battered her during the period of her pregnancy, and made an attempt to murder her. In this context, I noticed another unusual example of the "women against women" syndrome. Surprisingly, the mother of that student pressured Rasu in many ways to allow her husband to marry her daughter. One day the mother of the student reacted angrily to Rasu in the following way: "You neither allow your husband to remarry nor bring dowry-so you have to find out your own ways if they marry each other (Rasu)".

On the other hand, some women unknowingly became victims of the polygamy of their husbands. When these women came to know about their husbands previous marriages and asked about them, their husbands abused them. For example, Tonima's husband concealed the fact that he was married twice before and had children as well. Sriti, the most educated woman in this study, unknowingly became the victim of the second wife although her husband divorced his first wife before he married Sriti. However, quite often, it was a matter of altercation between them. There were some other examples 
of polygamy and extramarital relationship which largely acted as a critical source of the perpetuation of violence.

\section{In-law Syndrome}

One of the common factors of domestic violence in Bangladesh is the involvement of in-laws in the perpetuation of violence. Based upon the experiences of a number of participants, it is my firm conviction that in-laws instigate, either directly or indirectly, domestic violence against women. In this research, the participants mostly reported the involvement of their mother-in-laws in such perpetuation. Regarding the involvement of the mother-in-law, Hena's comment is worth mentioning. Her husband divorced her over the phone from abroad only based on the complains of her motherin-law. "Mother-in-laws become happier if their sons cannot live with their wives and if they abuse them. This is unfortunate for women. Once women become mother-in-laws, they forget that they were daughter-in-laws as well (Hena)".

Tanni's mother-in-law stopped her education and took possession of her jewelry. She also put pressure on her to bring a dowry and many issues related to domestic chores. Most shockingly, she imposed serious stigma on the character of Tanni and created grounds for abusing her by her husband:

Until two months after my marriage, I was not experiencing any menstruation. I could not understand the reason. Nevertheless, it happened when I came home for a visit, and that created the problem. My mother-in-law became suspicious. She told that I have released my illegal foetus at my parents' home. My husband also believed that and battered me (Tanni).

Joita had to engage in all sorts of domestic chores following the day of her marriage. If her mother-in-law would find any fault, she used to scold and batter her. Moreover, she always used to speak ill of her to his son. Her husband used to abuse her for all those complaints made by her mother. Similarly, the mother-in-laws of Nahar, Seuti, Rosy and Shirn not only physically and mentally abused them for different purposes, but also created scope for further violence by their husbands. Nahar depicted her experience: "My mother-in-law presents a tray full with ills of me, my husband swallows 
(abusing her) one by one (Naahr)". Seuti also shared an interesting experience: "My mother-in-law often secretly pours fresh water and adds salt and chilli so that food becomes insipid. My husband several times battered me for that, and other in-laws scolded me as well (Seuti)".

The mother-in-laws of both Babita and Benu were unhappy since Babita was expecting to give birth to a girl child and Benu already gave birth to female twins. The mother-in-law of Babita created a situation so that she was compelled to leave the husband's house and the mother-in-law of Benu told her husband to expel her from the home.

One of the important features of the in-law syndrome was the reluctance of the in-laws to prevent their sons from abusing their wives. A number of women reported that the perpetuation of violence went high since there was no intervention from their in-laws. I conceived the idea that it was an indirect support of the in-laws to perpetuate violence. One example follows: "When I complained to my mother-in-law about violence she said if you cannot manage your husband, it is your fault, I can do nothing (Sharifa)".

However, the findings above confirm that the in-laws particularly, the mother-in-law, influenced in myriad ways the perpetuation of domestic violence against many women in the study. Such violence is a very common factor in Bangladesh since in the traditional patriarchal and patrilocal family pattern women can be subjugated very easily by their in-laws. In a patriarchal and patrilocal system a woman's life becomes very complicated, not only in terms of discharging obligations and responsibilities to other members, but also in maintaining healthy relations with them.

\section{Childless or Sonless State}

Although the above category was not applicable to all the women, some women were abused in different ways by their husbands for being childless or sonless. In Bangladesh culture, it is still highly expected that a woman will not only produce child but also male child. A woman's status increases in the family if she can produce a male child. A woman is solely responsible for not giving birth to a child. It is assumed that men do not have problems. For example:

Immediately after marriage, we tried to have a baby, but failed. I asked him let us go to doctor for treatment. He replied, khanki magi 
(daughter of prostitute), how dare you ask me to go to doctor? If I marry again then you will understand whether I have problem or not (Hena).

He took a wine bottle and said, "You say I have problem; I will insert the bottle into your area so that it would produce baby" (Pallabi).

Women whose first child was a female encountered various forms of violence, but violence on this ground at least stopped once they could produce a male child; if not, it further escalated. Rosy, Nova, Kankan, Sharifa and so on reported that their first baby was a female, and for that they had to encounter a lot of violence by their husbands and in-laws, but they became happier when the next baby was a boy. Rosy's comment is worth mentioning:

During the birth of my first baby he warned me if you give birth to a female baby, I shall divorce you-although it was a female, but thanks Allah (God), he did not do anything like that (Rosy).

Benu could not give birth to a baby for around four years. Her husband and mother-in-law in many ways abused her for that. Finally, she gave birth to twin female babies, which made her life even more problematic. Knowing about the birth of twin female babies, her husband came back from the hospital without paying the bill. Benu's father had to pay it. After a few months, her husband expelled her from the home with the babies. She said: "My condition was relatively better when I had no baby, birth of these twins have made my life bad to worse (Benu)".

Amena thought that one of the reasons for her husband having extramarital relations and finally marrying a woman was her giving birth to three consecutive female children. He also called Amena opea (woman with bad luck) for that. For Bobita, the tracing of the prospective baby's sex as a female made her life seriously miserable. She had to leave her residence due to unbearable violence during the pregnancy.

\section{Questioning Husbands}

Some women confronted violence in different ways when they had questions about the various activities and habits of their husbands. The participants reported different bad habits of their husbands such as alcohol consumption, 
drug addiction, gambling, bingo playing, and so on, which generated many altercations between the wife and husband. Usually, husbands do not like to be questioned by their wives and in return, they use violent means to control them. Amongst all the bad habits, gambling was reported by the participants to be the most common habit of their husbands. For example, Suchanda stated the following:

He wastes a lot of money on gambling, if I ask him to stop, he beats and bullies me. Often says, "Am I playing with your father's money? I will waste my money as the way I want. You can only ask me to stop if you bring money from home" (Suchanda).

Apart from bad habits, low income, poverty, and indifference to performing familial activities by the husbands also generated violence. The husbands were in no way ready to be questioned about their income and responsibilities. Since most of the families in the study were of lower economic status, conflict concerning low income and poverty was integral within family life. Asking for daily necessities, income, pocket money, and maintenance easily paved the way for the escalation of violence. For example: "Many times, he punished me for asking him to increase money for family expenses (Champa)".

On the other hand, I mentioned before under forms of violence that Rahiman's husband uprooted one of her teeth. He attacked Rahiman since she questioned his income. Sharifa became extremely humiliated when her husband wanted to attack her vagina with a shovel in front her younger brother following an altercation on matters of family expenses.

\section{Not Meeting Expectations}

Not meeting the husbands' and in-laws' expectations in managing domestic chores or everyday activities often triggered violence. Most of the participants reported that they were under constant pressure in terms of cooking, serving meals, childcare, care of the in-laws, attention to husbands, washing clothes, and cleaning the house. With regard to the various expectations of the husbands, the following examples are worth-mentioning: 
I must make everything ready for the day before I go to school. Again, after coming from school, I have to take care for everything. I do not find rest. Even though, my mother-in-law and husband are not happy and find faults (Sriti).

I am always in a constant fix about cooking, if the food is not tasty, husband and in-laws scold me roughly. Sometimes they call me Akarmer dheki (unworth) and Baper bari hote kichu sekhe nai (nothing learnt from parents' home) (Kabita).

The behaviour of the children was always a problem for some women. The husbands used to blame the women if the children were naughty, if they did something wrong. They expected that it was a woman's responsibility to ensure proper behaviour of the children. The following excerpt of one of the participants represents the whole gamut of the husbands' expectations.

My husband does not like anything of me. Once he is at home, he only finds faults with me. If children are naughty-it is my fault; if the room is not tidyit is my fault; if his dress is not clean-it is my fault; if the plates and glasses are not clean-it is my fault; if he does not like the food-it is also my fault. My life is full with faults. Sometimes I think my existence is also a fault (Khodeja).

In fact, there were numerous examples of the husbands' expectations regarding everyday activities like the above, which many participants considered as easy sources for perpetuating violence against them.

\section{Discussion and Conclusions}

This paper brings some important observations on domestic violence in Bangladesh. It reveals six important factors which contribute significantly in triggering domestic violence: dowry demand, in-laws syndrome, childless or sonless state of women, not meeting husbands' expectations and questioning husbands. With regard to the analysing the causes of the phenomenon, I strongly reckon that the patriarchal structure and system of the society are broadly and dominantly interwoven in every aspect of this problem, although many features of this phenomenon were also linked up with other theoretical explanations discussed in the literature review of this paper. For example, according to sociological line of thought, poverty, insufficient and low- 


\section{Khan - Violence Against Rural Bangladeshi Women}

income are strongly correlated with domestic violence. My study also found that when women asked their husbands to increase their income or provide money for family expenses, their husbands became violent. According to a psychological line of thought, the women that were critical of their husbands' performance confronted more violence. Nevertheless, specifically, within patriarchy, various forms of abuse are the tools that perpetrators use to gain control and dominate women (Dobash and Dobash, 1976), and often use them interchangeably for establishing dominance and control (Monson, Langhinrichsen-Rohling, and Taft, 2009). I assumed that the system of patriarchy promoted the structure of violence in a number of ways by subordinating women. It was out of strong Bangladeshi patriarchal ideology that the perpetrators expected that women produce a child/preferably a male child, bring a dowry for them, meet all of their expectations, and never ask questions about their activities and responsibilities. One of the most common reasons for domestic violence is the demand of a dowry (Khan, 2001). With regard to the dowry demand, my assumptions went in line with an observation made by Naved and Persson (2005), which indicated that the demand for a dowry represented the true subordinate status of women in marital relations. The practice of a dowry demand in Bangladesh, particularly among the Muslims, dates back only some decades. Previously, the malice of a dowry demand existed only in the urban and affluent classes. Over the years it has rapidly spread to rural areas and has become deeply ingrained in the poorer section of the community (Huda, 2006). Two factors are closely associated with the demand for a dowry: increased greed and the commercialisation of marriage (Farouk, 2005). A dowry is an evil customary practice in Bangladesh, although an offense under the laws of Bangladesh. However, in most cases it is even demanded after marriage by the husband and his family (Khan, 2001). The positive association between dowry demand and violence against women has been traced by many studies in Bangladesh as well as in India (Rao, 1997; Banarjee, 1999; Bates et al., 2004; Naved and Persson, 2005; Naved and Persson, 2010). Out of a similar patriarchal ideology, some perpetrators restricted women's mobility, mariginalised them, took control of women's economic, social, sexual and reproductive lives and decisions, and so on. I think that poverty is also behind a lot of these bad actions related to dowry demand, and of course a lack of a meaningful life. On the other hand, although my study explored the violence that is perpetrated against women by 
their husbands, the findings of it found that the in-laws of the victims, particularly the mother-in-law, were equally liable for both the perpetuation and provocation of violence. The mother-in-law traditionally holds power over the daughter-in-law through her position as the husband's mother (Abraham, 2000). In my opinion, such a tendency greatly promotes patriarchal interest. By doing so, women become just the enemies of women (Ganguli and Rew, 2011) and unknowingly act in favour of the structure and system of patriarchy. However, such findings are consistent with the Nepalese context where it was found that in-laws, particularly, mothers-in-law, instigate domestic violence (Malla, Shrestha, Shrestha, Khadka, and Singh, 1999), and in the Indian context where other family members encourage or support violence (Dave and Solanki, 2000). In Bangladesh, the patrilocal residential pattern is the patriarchal norm which undermines women's autonomy (Mannan, 2002). Living in such a residential pattern, women easily become susceptible to various forms of violence by their in-laws. In my study, I found that the in-laws not only physically abused women; some male in-laws even sexually harassed them. In fact, when a married woman enters her husband's household, she assumes a weaker structural position as the daughter-in-law, subordinate to all men and senior women in the household (Kandiyoti. 1988). At the same time, my research identified much evidence, both from the women's experiences and community perceptions, of extramarital relations and practices of polygamy (permitted in Islam) as a source of different forms of violence. Such findings are consistent with the Thai findings, which state that due to the existence of "other women" in the husbands' life, many Thai women go through great troubles (Juree Vichit-Vadakan, 2000), and with the Chinese findings, which indicate that violence against women due to extramarital relations is an undisguised and unrestrained phenomenon in rural families (Wang, 1999). Predominantly, both of these are a symbol of the "women against women" game, which invariably promotes patriarchal interests. Specifically, in my opinion, as spouses are expected to be faithful to each other in Bangladeshi culture, men that have extramarital relations are displaying a kind of serious deviant behavior (Johnson and Das, 2009). With regard to polygamy, I assume that if polygamy is not legally stamped out completely, this system will continue to pierce the solemn structure of marital relations, and men will continue to take it for granted based on religious sanctions (Khan, 2001). 


\section{Khan - Violence Against Rural Bangladeshi Women}

Since it is a qualitative study, carried out with a limited number of participants and in some specific areas, the findings of this study may not be necessarily generalisable to a larger audience, even though my findings can be linked and elaborated in further studies in many ways with the broader context of Bangladesh concerning domestic violence. Due to time and resource constraints it was not possible for me to include many important and pertinent aspects of domestic violence against women. It is my firm conviction is that many important areas regarding to domestic violence are still unexplored and can be investigated by future researchers. Regarding policy implications, I suggest to make a wholesale structural reform concerning women's subordination in all aspects of the society. If women's subordination can be minimised, domestic violence against women can also be eliminated. At the same time there is a need for comprehensive effort from the end of government, non-government, local groups, and international organistaions to educate people about the harms of domestic violence, and must work together against this problem (Esquivel-Santoveña, Lambert and Hamel, 2013). We have to keep in mind that it is not an individual problem, rather a social and public problem, and should be treated as such.

\section{References}

Abraham, M. (2000). Speaking the unspeakable: Marital violence among south Asian immigrants in the United States. New Brunswick, NJ:

Rutgers University Press.

Amnesty International. (2004). It's in our hands: stop violence against women. London: Amnesty International Publications.

Banarjee, K. (1999). Gender stratification of marriage market in India. Journal of Family Issues, 648-676. doi: 10.1177/019251399020005005 Bates, L. M., Schular, S. R., Islam, F. \& Islam, M. K. (2004).

Socioeconomic factors and processes associated with domestic violence in rural Bangladesh. International Family Planning Perspectives, 30(4): 190-199. doi: 10.1363/ifpp.30.139.04

BBS. (2012). Population and housing census 2011. Bangladesh Bureau of Statistics (BBS), Ministry of Planning: Dhaka.

Bhuiya, Abbas, Sharmin, T. \& Hanifi, S.M. (2003). Nature of Domestic

Violence against Women in a Rural Area of Bangladesh: Implication for 
Preventive Interventions. Journal of Health Population \& Nutrition, 21(1), 1729-1742.

Braun, V., \& Clarke, V. (2006). Using thematic analysis in psychology.

Qualitative Research in Psychology, 3, 77-101. doi:

10.1191/1478088706qp063oa

Creswell, J. W. (2013). Qualitative inquiry and research design choosing among five traditions $\left(3^{\text {rd }} \mathrm{edt}\right)$. Thousand Oaks: Sage.

Crowell, N. A., \& Burgess, A. W. (1996). Understanding violence against women. Washington DC: National Academy Press.

Dave, A. \& Solanki, G. (2000). Special cell on women and children: A research study on domestic violence. In unnamed (summery report), Domestic Violence in India: A summary report of four studies (pp. 2533). Washington DC: International Centre for Research on Women (ICRW).

DeKeseredy, W. S., \& Schwartz, M. D. (2011).Theoretical and definitional issues in researching violence against women. In C. M Renzetti, J. L Edleson, \& R. K. Bergen (Eds.), Source book on violence against women (pp 1-20). Thousand Oaks: Sage.

Dobash, R. E., \& Dobash, R. P. (1979). Violence against Women: A case against the patriarchy. New York: Free Press.

Edwards, S. S. M. (1989). Policing domestic violence: Women the law and the state. London: Sage.

Ellesberg, M., Heise, L., Peña, R., Augurto, S., \& Winkvist, A. (2001). Researching domestic violence against women: Methodological and ethical considerations. Studies in Family Planning, 32 (1): 1-15. doi: 10.1111/j.1728-4465.2001.00001.x

Esquivel-Santoveña, E., Lambert, T., \& Hamel, J. (2013). Partner Abuse Worldwide. Partner Abuse, 4(1), 6-75. doi: 10.1891/1946-6560.4.1.6

Farouk, S. A. (2005). Violence against women: a statistical overview, challenges and gaps in data collection and methodology and approaches for overcoming them. Geneva: UN Division for the Advancement of Women. Retrieved May 4, 2013, from

http://www.un.org/womenwatch/daw/egm/vaw-stat-2005/docs/expertpapers/Farouk.pdf

Ganguli, G., \& Rew, M. (2011). Mothers-in-law against daughters-in-law: Domestic violence and legal discourses around mother-in-law violence 
against daughters-in-law in India. Women's Studies International Forum, 34: 420-429. doi: 10.1016/j.wsif.2011.06.006

Hattery, A. (2009). Intimate partner violence. Lanham: Rowman \& Littlefield Publishers, Inc.

Hearn, J. (1996). 'Men's violence to known women: Historical, everyday and theoretical constructions by men'. In B. Fawcett, B. Featherstone, J. Hearn \& C. Toft (eds.) Violence and gender relations-Theories and interventions. London: Sage, pp. 22-37.

Hearn, J. (1998). The violence of men. London: Sage.

Hird, M. J. (2002). Endangering violence. Ashgate: Aldershot.

Hennink, M., Hutter, I. \& Bailey, A. (2011). Qualitative research methods. London: Sage.

Huda, S. (2006). Dowry in Bangladesh: Compromising women's rights.

South Asia Research, 26 (3): 249-268. doi:

10.1177/0262728006071707

Johnson, K. B., \& Das, M. B. (2009). Spousal violence in Bangladesh as reported by men: Prevalence and risk factors. Journal of Interpersonal Violence, 24 (6): 997-995. doi: 10.1177/0886260508319368

Johnston, H. B., \& Naved, R. T. (2008). Spousal violence in Bangladesh: A call for a public-health response. Journal Health Population Nutrition, 26 (3): 366-377. doi: 10.3329/jhpn.v26i3.1903

Juree Vichit-Vadakan (2000). Violence against women: A Thai perspective. Bangkok: Centre for Philanthropy and Civil Society, NIDA.

Kandiyoti, D. (1988). Bargaining with patriarchy. Gender and Society, 2: 274-290.

Kelly, L. (1996). Tensions and possibilities: Enhancing informal responses to domestic violence. In J. L. Edleson, \& Z. C. Eisikovit (Eds.), Future interventions with battered women \& their families: Sage series on violence against women volume III (pp. 67-86). Thousand Oaks: Sage.

Khan, S. R. (2001). The socio-legal status of Bengali women in Bangladesh: Implications for development. Dhaka: UPL.

Khatun, T \& Rahman, K. F. (2012). Domestic violence against women in Bangladesh: Analysis from a socio-legal perspective, Bangladesh eJournal of Sociology, 9 (2): 19-29. 
Koenig, M. A., Ahmed, S., Hossain, M.B. \& Khorshed, A. M. A. B. (2003).

Women's status and domestic violence in rural Bangladesh: Individual

and community level effects. Demography, 40 (2): 269-288.

Levy, B. (2008). Women and violence. Berkeley, CA: Seal Press.

Mannan, M. A. (2002). Violence against women: Marital violence in rural

Bangladesh. Dhaka: Centre for Policy Dialogue. Retrieved April 12,

2013, from http://www.cpd-

bangladesh.org/publications/cpdunfpa/unfpa20.PDF

Malla, S.P., Shrestha, I., Shrestha, A., Khadka, B., \& Singh, I. (1999).

Violence against women and girls in Nepal. In In F. M. Cheng, M.

Karlerker, A. D. Dios, Juree Vichit-Vadakan \& L. R. Quisumbing (Eds.),

Breaking the Silence: Violence against Women in Asia (pp 139-151).

Hong Kong: Equal Opportunities Commission.

Marshall, C. \& Rossman, G. B. (1999). Designing qualitative research ( $1^{\text {st }}$

$E d s)$. Thousand Oaks: Sage.

Maynard, M. \& Winn, J. (1997). Women, violence and male power. In V.

Robinson \& D. Richardson (Eds.), Introducing women's studies (pp. 175-

197). Basingstoke: Palgrave.

Mason, J. (2002). Qualitative researching. London: Sage.

McCue, M. L. (2008). Domestic violence-A reference handbook. Santa Barbara: ABC-CLIO, Inc.

Monson, C. M., Langhinrichsen-Rohling, J., \& Taft, C. T. (2009) Sexual aggression in intimate relations. In O'Leary, K. D. \& Woodin, E. M. (Eds.), Psychological and physical aggression in couples: causes and interventions (pp. 37-58). Washington D.C: American psychological Association.

Moony, J. (2000). Gender, violence and social order. Basingstoke:

Macmillan Press.

Naved, R. T. (2013). Sexual violence towards married women in

Bangladesh. Archives of Sexual Behaviour, 42: 595-602. doi:

10.1007/s10508-012-0045-1

Naved, R. T., \& Persson, L. Å. (2005). Factors associated with spousal physical violence against women in Bangladesh. Journal of Family Planning, 36 (4): 289-300. doi: 10.1111/j.1728-4465.2005.00071.x Naved, R. T., \& Persson, L. Å (2010). Dowry and spousal physical violence women in Bangladesh. Journal of Family Issues, 31 (6): 830-856. doi: 10.1177/0192513X09357554 
Perillia, J. L., Lippy, C., Rosales, A., \& Serrata, J.V. (2011). Prevalence of domestic violence. In J. W. White, M. P. Koss, \& A. E. Kazdin (Eds.). Violence against women and children: Mapping the terrain (Vol.1) (pp.199- 220).Washington D.C: American Psychological Association. Rao, V. (1997). Wife-beating in rural south India: A qualitative and econometric analysis. Social Science \& Medicine, 44, 1169-1180. doi: 10.1016/S0277-9536(96)00252-3

Richardson, J., Coid, J., Petruckevitch, A., Chung, W. S., Moorey, S., \& Feder, G. (2002). Identifying domestic violence: Cross-sectional study in primary care. British Medical Journal, 324: 274-277. doi:

10.1136/bmj.324.7332.274

Romito, P. (2008). A deafening silence: Hidden violence against women and children. Bristol: The Policy Press.

Rossman, G. B. \& Rallis, S. F. (2012). Learning in the field: An introduction to qualitative research. Thousand Oaks: Sage.

Salam, A., Alim, A. \& Noguchi, T. (2006). Spousal abuse against women and its consequences on reproductive health: A study in the urban slums in Bangladesh. Maternal and Child Health Journal, 10 (1): 83-94. doi: 10.1007/s10995-005-0030-6

Schular, S. R., Hashemi, S.M., Riley, A. P., \& Akhter, S. (1996). Credit programs, patriarchy and men's violence against women in rural Bangladesh. Social Science and Medicine, 43 (12): 1729-1742. doi: 10.1016/S0277-9536(96)00068-8

Siddiqi, D. M. (2006). One step forward, two steps back? Women's rights in 2005. In H. Hossain (Ed.), Human rights in Bangladesh 2005 (pp. 197216). Dhaka: Ain o Salish Kendra (ASK).

Skinner, T., Hester, M., \& Malos, E. (2005). Researching gender violence: Feminist methodology in action. Abingdon: Willan.

Stacey, J. (1993). Untangling feminist theory. In V. Robinson \& D.

Richardson (Eds), Introducing women's studies (pp. 49-73). Basingstoke: Palgrave.

Thiel, S. V. (2014). Research methods in public administration and public management. London: Routledge.

Tonsing, J. C. (2014). A study of domestic violence among south Asian women in Hong Kong (Doctoral dissertation). Centre for Criminology and Sociology, University of London. Retrieved December 6, 2014 from 
https://pure.royalholloway.ac.uk/portal/files/19440165/Jenny_thesis_PhD _2014_.pdf

Wang, X. (1999). Domestic violence in china. In F. M. Cheng, M. Karlerker, A. D. Dios, Juree Vichit-Vadakan, \& L. R. Quisumbing (Eds.), Breaking the Silence: Violence against Women in Asia (pp. 13-37). Hong Kong: Equal Opportunities Commission.

Walby, S. (1996). The 'declining significance' of the 'changing forms' of patriarchy? In V. M. Moghadam (Ed.), Patriarchy \& economic development: Women's positions at the end of the twentieth century (pp. 19-33). Oxford: Clarendon.

WHO (2001). Putting Women First: Ethical and Safety Recommendations for Research on Domestic Violence Against Women. Geneva: World Health Organisation. Retrieved March 12, 2012 from http://www.who.int/gender/violence/womenfirtseng.pdf.

Women's Aid (2009). Domestic violence: Frequently asked questions factsheet 2009. Retrieved February 21, 2013, from http://www.womensaid.org.uk/domestic-violencearticles.asp?section $=00010001002200410001 \&$ itemid $=1272$

Yodanis, C, L. (2004). Gender inequality, violence against women and fear: A cross-national test of feminist theory of violence against women. Journal of Interpersonal Violence, 19 (6): 655-675. doi: $10.1177 / 0886260504263868$

\footnotetext{
Anisur Rahman Khan Assistant Professor in the Department of Social Relations at East West University.

Contact address: Department of Social Relations. A/2, Jahurul Islam City Gate, 1212, Aftab Nagar Main Rd, Dhaka, Bangladesh

E-mail address: khanpatc@gmail.com
} 


\section{Géneros}

Multidisciplinary Journal of Gender: Studies
Hipatia Press

www.hipatiapress.com

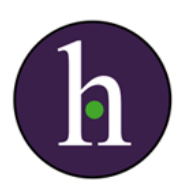

Instructions for authors, subscriptions and further details:

http://generos.hipatiapress.com

Violencia de pareja contra las mujeres en México: una mirada a la atención del sector salud desde una perspectiva interseccional

Anahely Medrano ${ }^{1,2}$

Martha Miranda ${ }^{2}$

Victor Manuel Figueras ${ }^{2}$

1) Consejo Nacional de Ciencia y Tecnología. México

2) Benemérita Universidad Autónoma de Puebla. México

Date of publication: February $25^{\text {th }}, 2017$

Edition period: February - June 2017

To cite this article: Medrano, A., Miranda, M. \& Figueras, V. M. (2017).

Violencia de pareja contra las mujeres en México: una mirada a la atención del sector salud desde una perspectiva interseccional.

Multidisciplinary Journal of Gender Studies, 6(1), 1231-1262. doi:

10.4471/generos.2017.2131

To link this article: http://dx.doi.org/10.4471/generos.2017.2131

PLEASE SCROLL DOWN FOR ARTICLE

The terms and conditions of use are related to the Open Journal System and to Creative Commons Attribution License (CC-BY). 


\section{Partner violence against women in México: a look at the attention of the health sector from an intersectional perspective}

Anahely Medrano

CONACYT-BUAP

Victor Manuel Figueras

BUAP
Martha Miranda

$B U A P$

\section{Abstract}

In Mexico, violence against women is a social pandemic. Most of this violence is generated in the home, usually at the hands of their partners. The range of actions that the government, and society in general, can implement to attend this problem is ample; particularly the health sector performance in this work is crucial. Given the persistence of this problem, the analysis of how the health sector has responded to it is essential for designing more effective public policies. The aim of this paper is to analyze the differences in the public health response to women victims of violence in Mexico, from an intersectional perspective. To do this, this quantitative analysis is based on data ENDIREH 2011. The results show that serious problems of attention to battered women in the health sector persist. These problems are widespread among different groups of women; no substantial differences prevail among indigenous women or those living in poverty. These results warn of implications of the health sector deficiencies on the wellbeing of women affected by domestic violence.

Keywords: partner violence, intersectionality, poverty, health sector 


\section{Violencia de pareja contra las mujeres en México: una mirada a la atención del sector salud desde una perspectiva interseccional}

Anahely Medrano

CONACYT-BUAP

Victor Manuel Figueras

BUAP

\section{Resumen}

En México, la violencia contra las mujeres es una pandemia social. La mayor parte de esta violencia se genera en el ámbito doméstico, comúnmente a manos de sus parejas. El abanico de acciones que el gobierno, y la sociedad en general, pueden poner en práctica para atender este problema es amplio; particularmente, el desempeño del sector salud en esta labor es fundamental. Ante la persistencia de este problema, el análisis de la forma en que el sector salud ha respondido al mismo resulta indispensable para diseñar políticas públicas más efectivas. El objetivo de este trabajo es analizar las diferencias en el trato que reciben las mujeres víctimas de violencia en diferentes entidades del sector salud en México, desde una perspectiva interseccional. Para ello, se realiza análisis cuantitativo con base en los datos de ENDIREH 2011. Los resultados muestran que persisten serios problemas de atención a mujeres violentadas en el sector salud. Estos problemas son generalizados entre distintos grupos de mujeres; no hay diferencias sustanciales entre las que están en condición de pobreza o son indígenas. Estos resultados advierten sobre las implicaciones de las deficiencias registradas por parte de las instituciones públicas para el bienestar de mujeres que sufren violencia.

Palabras clave: violencia de pareja íntima, interseccionalidad, pobreza, sector salud

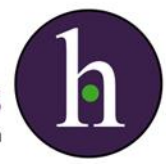





\section{Medrano, Miranda \& Figueras - Violencia de pareja contra las mujeres en México}

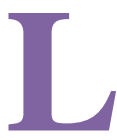

as distintas violencias que padecen las mujeres se han clasificado a partir de varios criterios, que incluyen desde el tipo de violencia perpetrado (por ejemplo, física, sexual o emocional, entre otras) hasta el ámbito o espacio donde se desarrolla la violencia (por ejemplo, ámbito doméstico o familia). Más allá de las clasificaciones, la violencia contra mujeres, en diferentes manifestaciones, se reconoce como un problema multidimensional y multifactorial, el cual está profundamente enraizado en las relaciones de poder históricamente desiguales entre mujeres y hombres, así como en los estereotipos de género y los valores culturales vinculados al estructuras patriarcales (ONU, 2015). Debido a que las violencias contra mujeres están íntimamente vinculadas a la desigualdad de género, la "violencia de género" se ha convertido en un término aceptado internacionalmente para hacer referencia a la violencia física, sexual y psicológica contra las mujeres. Asimismo, la violencia de género representa un problema extendido que tiene efectos devastadores en la salud y el bienestar de mujeres (Goicolea et al., 2015; Valdez et al., 2006; Ruiz et al., 2004).

Este estudio se centra en la violencia contra las mujeres por parte de la pareja íntima (VPI) en México. Los hogares constituyen un escenario típico de violencia de género, siendo las mujeres y los menores de edad las víctimas frecuentes, mientras que los hombres son los principales perpetradores. Aunque la violencia doméstica comprende abusos de carácter psicológico, emocional, físico y sexual de un miembro del hogar sobre otro, la VPI sólo considera la violencia contra las mujeres perpetrada por sus respectivas parejas íntimas, quienes generalmente son hombres. En este estudio, se utilizará de manera indistinta violencia de pareja y violencia contra mujeres en ámbito doméstico (VPI), aun cuando el espacio físico en el que se desarrolla la violencia no se circunscribe al hogar en el que habitan los implicados en procesos de violencia familiar. Para efectos de este estudio, la VPI se define como "cualquier comportamiento dentro de una relación íntima que causa daño físico, sexual o psicológico, incluidos los actos de agresión física, coacción sexual, abuso psicológico y comportamientos controladores " (Goicolea et al., 2015, p.2). 
La violencia contra las mujeres a manos de sus parejas continúa siendo un problema crónico y endémico de salud pública en México. Según datos de la ENDIREH (2011), 56\% de mujeres casadas o unidas reportaron haber padecido violencia en algún momento de su vida. Otro dato relevante alarmante es que el porcentaje de mujeres que fueron violentadas en los últimos 12 meses anteriores a la encuesta y que no denunciaron dichas agresiones es de 88.9\% (ENDIREH, 2011). Es decir, sólo 11 de cada 100 mujeres mexicanas denuncia la violencia que ha sufrido. La lista de factores que inhiben la denuncia ante autoridades por parte de mujeres violentadas es amplia. Aunque no es tema de este trabajo discutir estos factores, algunos de éstos se vinculan con el desempeño del sector salud en los procesos de atención y prevención de este grave problema social, como se discute más adelante.

De la misma forma en la que violencia contra las mujeres responde a múltiples factores, la respuesta esperada ante este problema por parte del gobierno -y de la sociedad en su conjunto - incluye una gama amplia de acciones encaminadas a la atención y prevención del mismo. Por varias causas, la respuesta del sector salud resulta particularmente estratégico para atender y prevenir apropiadamente la violencia contra mujeres. No obstante, en países en desarrollo, el involucramiento del sector salud para atender este problema ha sido generalmente lento o insuficiente (Ellsberg, et al. 2015). Por ello, entre otras razones, resulta indispensable conocer la dinámica y características de la respuesta del sector salud ante VPI. Este estudio se enfoca a un área de acción crucial en este tema: la atención que se brinda a mujeres en las distintas instancias que conforma el sector salud en México.

En particular, este análisis se centra en la atención que reciben las mujeres violentadas en el sector salud, y que implica una interacción directa entre ellas y el personal de las organizaciones de salud. Este estudio explora las percepciones de las propias usuarias de servicios de salud que han acudido a consecuencia de la violencia padecida en sus hogares, a cerca del trato que recibieron en dichos servicios. En particular, este estudio se enfoca en observar el cumplimiento de ciertas acciones que se consideran, según la normatividad, como parte de una respuesta apropiada y oportuna del sector salud ante la violencia contra las mujeres. Así, el objetivo de este estudio es observar la diferencia entre las respuestas de atención del sector 


\section{Medrano, Miranda \& Figueras - Violencia de pareja contra}

las mujeres en México

salud a la violencia contra las mujeres, por cada grupo incluido en el estudio. Esto, con la intención de observar, desde una perspectiva intersectorial, la calidad de servicios que brinda el sector salud a las mujeres que han padecido violencia por parte de su pareja en México.

Este documento se integra de tres apartados principales. En el primer apartado se discute de manera general la importancia de considerar un enfoque interseccional para estudiar la violencia contra mueres. En el segundo apartado se ofrecen en breve panorama de las cifras de violencia contra mujeres en México. El tercer apartado incluye una descripción de los datos y metodología del estudio. En el cuarto apartado se incluyen los principales resultados del estudio. En la quinta parte, se discuten brevemente los resultados. Al final, se ofrecen comentarios breves a manera de conclusión.

\section{Interseccionalidad y el estudio de la violencia contra las mujeres}

Al igual que otros tipos de violencia contra mujeres, la VPI es un problema multidimensional y multifactorial (ONU, 2015). La interseccionalidad ha ganado terreno como estrategia analítica para entender este problema. En general, la interseccionalidad se refiere a una visión crítica que considera que la clase social, género, etnia, nación, edad, entre otras categorías, "no operan como entidades unitarias que se excluyen mutuamente, sino como construcción recíproca de fenómenos" (Hill, 2015, p.3). Así, la interseccionalidad es una perspectiva para desempaquetar las causas y dimensiones de la opresión de las mujeres, que en la realidad operan de forma múltiple y simultánea (Muñoz, 2010). La incorporación de esta perspectiva de análisis de la VCM significa que el género no se estudia como una categoría aislada sino en conjunto con otras categorías, en particular las categorías de clase social y raza u origen étnico (Bent, 2004; Josehpson, 2002; Burman y Chantler, 2005; Conwill, 2009). Por lo tanto, una perspectiva interseccional permite entender cómo los diferentes conjuntos de identidades de las personas impactan en el disfrute efectivo de sus derechos, lo que incluye el acceso a bienes y servicios sociales, tales como salud.

Desde una perspectiva intersectorial, de una manera similar en el que la experiencia de VPI difiere en las mujeres según la raza, etnia y clase social 
(Koening et al, 2003; Conwill, 2009; Sokoloff y Dupont, 2005; Pitt, 2008), las víctimas pueden obtener una respuesta diferente del sector salud sobre la misma base. En particular, los estudios sobre la intersección de las categorías socioeconómicas, raciales o étnicas y la respuesta del sector salud ante la violencia contra mujeres se han centrado en las disparidades en el acceso al cuidado de la salud, la calidad de ciertos servicios, tales como pruebas y procedimientos específicos (Cha y Masho, 2014, p.1420). Sin embargo, un área menos explorada en la literatura, desde un enfoque interseccional, es los servicios que implica interacción personal entre personal médico y mujeres violentadas, los cuales están relacionadas con otros aspectos de la atención que son claves para el tratamiento, prevención de la violencia que sufren las mujeres. Precisamente, este trabajo pretende contribuir al estudio de la respuesta del sector salud a la violencia contra mujeres, desde una visión interseccional.

En particular, este estudio pone atención a las categorías de estatus socioeconómico (situación de pobreza extrema) y etnicidad (pertenencia a un grupo indígena) en México. Dadas las condiciones sociodemográficas de este país, las categorías antes mencionadas son altamente relevantes para el análisis en tema que ocupa este trabajo. En 2014, según cifras oficiales, $46.2 \%$ de la población total vivía en condiciones de pobreza (CONEVAL, $2015)^{1}$. La pobreza tiende a ser aún más acentuada y generalizada en comunidades rurales y predominantemente indígenas. En ese mismo año, $73.2 \%$ y $65.1 \%$ de la población indígena y rural, respectivamente, vivía en alguna condición de pobreza (CONEVAL, 2015). En el siguiente apartado, se ofrece un panorama de la magnitud de violencia contra mujeres, por distintos grupos, en México.

\section{La relevancia del sector salud para atender y prevenir violencia contra mujeres}

Del conjunto de acciones que el gobierno puede poner en práctica para atender y prevenir la violencia contra mujeres en el ámbito doméstico, un importante número corresponde al sector salud. En particular, la red de servicios de atención médica y hospitalaria desempeña una labor fundamental, ya que además de prestar servicios de atención médica a las víctimas de VPI, también tiene asignadas ciertas acciones que implican 


\section{Medrano, Miranda \& Figueras - Violencia de pareja contra las mujeres en México}

interacción directa con tales víctimas, las cuales son cruciales para lograr atender, prevenir y dar seguimiento de manera efectiva este problema social. Por ello, varias instancias internacionales, destacando la Organización de las Naciones Unidas (ONU) y la Organización Mundial de la Salud (OMS), han insistido en enfatizar el papel fundamental que tienen los prestadores de salud públicos y privados para atender y prevenir la VPI, ya que los profesionales de la salud-médicos y demás personal que tiene contacto con las mujeres que acuden al sector salud- representan la primera $-\mathrm{y}$ frecuentemente la única- instancia de gobierno con las que las víctimas tienen contacto durante los episodios de violencia.

En consecuencia, este personal está en una posición clave para que, más allá de brindar a las mujeres víctimas de violencia la atención médica requerida por alguna lesión o daño, pueden proporcionar otros servicios de asistencia y prevención, tales como apoyo sicológico y, además, la canalización adecuada a otros servicios, especialmente de trabajo social o jurídico, entre otros (ONU, 2015; OMS, 2013). Asimismo, las funciones del sector salud también permite el seguimiento de los eventos de violencia, así como la recopilación de pruebas forenses, particularmente en los casos de violencia sexual, así como otra información que pueda ser útil al momento de iniciar un proceso judicial. De manera similar, la adecuada canalización a servicios sicológicos es importante para prevenir o, incluso, atender de manera integral a las mujeres que acuden a consecuencia de un incidente de violencia doméstica.

De esta forma, la OMS ha dictado recomendaciones básicas para proporcionar una respuesta adecuada por parte del sector salud. Este directrices sugieren, entre otras, que los proveedores de salud deben: 1) identificar adecuadamente el abuso; 2) proporcionar apoyo médico adecuado; 3) proporcionar apoyo emocional; 4) documentar episodios de VPI; proporcionar información y remitir adecuadamente a las víctimas hacia trabajo social, servicios jurídicos y psicológicos (Chang et al, 2005; Colombini et al, 2007; OMS, 2013). Además de las recomendaciones que se refieren directamente a la adecuada atención de las víctimas de violencia (por ejemplo, intervención clínica y de apoyo emocional), la OMS ha resaltado la importancia de que los gobiernos pongan en práctica o fortalezcan programas para la prevención y combate a la violencia contra 
las mujeres, especialmente la ejercida por parte de sus parejas, así como mejorar permanentemente la capacitación y especialización de los trabajadores del sector salud (OMS, 2013).

La legislación mexicana incorpora algunas de las principales recomendaciones de la OMS. Para ello, existen varios protocolos o lineamientos generales de atención a mujeres que han padecido violencia, destacadamente la NOM-046-SSA2-2005, el Modelo Integrado para la prevención y atención de la violencia familiar y sexual (2009) y el Catálogo Universal de Servicios de Salud (2015). Así, esta normatividad dispone acciones generales y concretas que el sector salud debe poner en práctica para atender a mujeres que han sido víctimas de violencia. De acuerdo con esta normatividad, el sector salud constituye el principal encargado de la identificación, atención y canalización de los casos de violencia contra las mujeres en la pareja, destacando la posición estratégica de los trabajadores de este sector. El cuadro de abajo se pueden observar el amplio abanico de acciones que contempla la NOM-046-SSA2-2005, cubriendo varios ejes de acción que debe poner el sector salud para atender este grave problema social.

\section{Cuadro 1}

Algunas de las principales acciones que establece la NOM-046-SSA2-2005

para atender mujeres que han padecido violencia

\begin{tabular}{|c|c|}
\hline Ejes & \multicolumn{1}{c|}{ Acciones } \\
\hline & $\begin{array}{c}\bullet \text { Realizar entrevista dirigida a la o el usuario afectado por violencia } \\
\text { familiar o sexual, en un clima de confianza, sin juicios de valor ni }\end{array}$ \\
$\begin{array}{c}\text { Detección de } \\
\text { probaicios, con respeto y privacidad, garantizando confidencialidad. }\end{array}$ \\
y diagnóstico \\
$\begin{array}{c}\bullet \text { En caso de que la o el usuario no esté en condiciones de responder } \\
\text { durante la entrevista, la o el prestador se dirigirá, a su acompañante, } \\
\text { sin perder de vista que pudiera ser el probable agresor. Cuando la } \\
\text { imposibilidad de la o el usuario se deba al desconocimiento del } \\
\text { español, deberá contar con el apoyo de un traductor. }\end{array}$ \\
\hline
\end{tabular}




\begin{tabular}{|c|c|}
\hline S & Acciones \\
\hline $\begin{array}{c}\text { Tratamiento y la } \\
\text { rehabilitación }\end{array}$ & $\begin{array}{l}\text { - Brindar atención integral a los daños tanto psicológicos como físicos } \\
\text { así como a las secuelas específicas, refiriéndolos, en caso de ser } \\
\text { necesario, a otros servicios, unidades médicas, instituciones y } \\
\text { organismos. } \\
\text { - En todos los casos se deberá ofrecer atención psicológica a las } \\
\text { personas que viven o han vivido en situaciones de violencia familiar } \\
\text { o sexual. } \\
\text { - Impartir consejería en los servicios médicos, con personal } \\
\text { capacitado, que facilite un proceso de comunicación y análisis y } \\
\text { brinde elementos para que la o el usuario tome decisiones } \\
\text { voluntarias, conscientes e informadas sobre las alternativas para la } \\
\text { prevención y atención de la violencia. }\end{array}$ \\
\hline $\begin{array}{c}\text { Tratamiento } \\
\text { específico de la } \\
\text { violación sexual }\end{array}$ & $\begin{array}{l}\text { - Estabilizar, reparar daños y evitar complicaciones a través de } \\
\text { evaluación y tratamiento de lesiones físicas. } \\
\text { - Proporcionar consejería, seguimiento y orientación a la persona } \\
\text { afectada sobre las instituciones públicas, sociales o privadas a las que } \\
\text { puede acudir para recibir otros servicios. }\end{array}$ \\
\hline $\begin{array}{l}\text { Aviso al } \\
\text { ministerio } \\
\text { público }\end{array}$ & $\begin{array}{l}\text { - Elaborar el aviso al Ministerio Público mediante el formato } \\
\text { establecido, en los casos donde las lesiones u otros signos sean } \\
\text { presumiblemente vinculados a la violencia familiar o sexual. } \\
\text { - Ante lesiones que en un momento dado pongan en peligro la vida, de } \\
\text { la o el usuario se dará aviso de manera inmediata al Ministerio } \\
\text { Público. } \\
\text { - En los casos en los cuales las lesiones que presente la persona no } \\
\text { constituyan un delito que se siga por oficio, el médico tratante } \\
\text { informará a la o el usuario afectado, sobre la posibilidad que tiene de } \\
\text { denunciar ante la agencia del Ministerio Público. }\end{array}$ \\
\hline $\begin{array}{l}\text { Consejería y el } \\
\text { seguimiento }\end{array}$ & $\begin{array}{l}\text { - Corresponde a las y los prestadores informar a la persona afectada } \\
\text { sobre su derecho a denunciar los hechos de violencia, la existencia de } \\
\text { centros de apoyo disponibles, así como los pasos a seguir para } \\
\text { acceder a los servicios de atención, protección y defensa facilitando y } \\
\text { respetando sus decisiones. }\end{array}$ \\
\hline
\end{tabular}




\begin{tabular}{|c|c|}
\hline Ejes & Acciones \\
\hline & $\bullet$ Las y los prestadores de servicios de salud deberán recibir \\
Sensibilización, & periódicamente sensibilización, capacitación y actualización, sobre \\
capacitación y & procedimientos para el registro de casos y aviso al Ministerio \\
actualización & Público, información sobre centros especializados para el \\
& tratamiento, consejería y asistencia social, entre otros temas. \\
\hline
\end{tabular}

Fuente: Elaboración propia con datos de la NOM-046-SSA2-2005.

Como se puede observar, varias de las acciones que contempla la normatividad antes mencionada se refiere a la prestación de servicios interpersonales, los cuales incluyen, además de la atención estrictamente médica o curativa, indagar sobre el motivo de la visita médica, referir o canalizar oportunamente hacia otros servicios (por ejemplo, asesoría psicológica, de trabajo social o jurídica), entre otros. Estos servicios son indispensables para un tratamiento integral, así como la prevención y seguimiento de casos de violencia. De ésta manera, un trato adecuado, es decir, que, en principio, se alinea con los protocolos de atención para mujeres víctimas de violencia, implica cumplir con las acciones dirigidas a brindar una oportuna información y canalización para que las mujeres víctimas de violencia tengan acceso a otros servicios o instancias (por ejemplo, acudir a instancias pertinentes para denunciar la comisión de delito). Además, entre otros aspectos, el trato adecuado excluye cualquier comunicación crítica, actitudes discriminatorias o desconsideradas por parte de los proveedores hacia los usuarios de atención de salud.

La oportunidad y la forma del trato personal que implican estos servicios tienen un impacto directo en la calidad del servicio prestado para atender y prevenir la violencia contra mujeres. No obstante, diversos estudios reportan que las mujeres que han padecido violencia por parte de su pareja y recurren al sector salud por ese motivo, reciben servicios deficientes (Plichta, 2007; Tower, 2007; Taket et al., 2003; McGrath, 1997; Waalen et al., 2000). En México, los obstáculos para lograr una atención y prevención adecuada por parte del sector salud al problema de la violencia incluye diversos factores, entre los cuales figuran desde fallos estructurales en las organizaciones de la salud hasta limitaciones por parte del personal que labora en las mismas (ver Herrara, 2013). En general, estas investigaciones se centran en las principales deficiencias u obstáculos por parte de los 


\section{Medrano, Miranda \& Figueras - Violencia de pareja contra las mujeres en México}

agentes encargados de poner en práctica la normatividad de atención para violencia en el sector salud, especialmente por parte del personal médico y enfermeras (Cervantes, 2013; Herrera, et al. 2006; Híjar, Ávila-Burgos, Valdez-Santiago, 2006; Méndez-Hernández, et al., 2003; Tiburcio, Natera, Berenzon, 2010; Venegas, et al., 2007).

Entre algunas de esas deficiencias en el trato que reciben las mujeres en el sector salud están la falta o insuficiente capacitación del personal médico para aplicar la normatividad vigente, así como la falta de interés o poca sensibilidad para atender a las mujeres violentadas, entre otros (Cervantes, 2013; Herrera, et al. 2006; Híjar, Ávila-Burgos, Valdez-Santiago, 2006; Méndez-Hernández, et al., 2003; Tiburcio, Natera, Berenzon, 2010; Venegas, et al., 2007). En consecuencia, se incumplen varias de las acciones que resultan primordiales para garantizar un trato adecuado a las mujeres que acuden al sector salud. La prestación deficiente de atención de la salud tiene varias implicaciones sobre el bienestar y dignidad de las víctimas. Tales deficiencias también pueden generar desconfianza entre las usuarias hacia las organizaciones de salud, inhibiendo no sólo la denuncia de la violencia, sino el uso mismo de los servicios que prestan tales organizaciones. Incluso, la inadecuada respuesta del sector salud puede implicar un segundo proceso de victimización de las mujeres (Herrera, 2013).

Por esta razón, diferentes organizaciones internacionales han señalado la urgencia de mejorar la respuesta del sector salud a la violencia basada en el género, especialmente en los países en desarrollo (OMS, 2013). Para lograr lo anterior, resulta indispensable conocer la magnitud y causas de las fallas en la implementación de los protocolos de atención de víctimas de violencia en el sector salud. El presente trabajo pone énfasis en algunas de las acciones que, según la normatividad vigente, corresponde al sector salud. En particular, este trabajo se enfoca a ciertas acciones que implica interacción directa entre las mujeres víctimas de violencia y el personal de las organizaciones de salud, tales como indagación sobre el motivo de la visita médica o diagnóstico, la referencia o canalización hacia otros servicios (por ejemplo, asesoría psicológica o jurídica), entre otros.

Así, este estudio analiza la manera en que el sector salud está actuando ante este problema, según las percepciones de las mujeres que han padecido 
violencia, según la ENDIREH 2011. Para ello, este análisis comprende dos partes. En la primera parte, se identifica la respuesta, en términos de la calidad de atención de ciertos servicios interpersonales, de diferentes prestadores de servicios del sector salud, especialmente públicos, según las percepciones de las mujeres que recibieron atención por parte de tales organismo. La segunda parte se explora las potenciales desigualdades por origen étnico o situación de pobreza en la respuesta de atención del sector salud a la violencia contra las mujeres. Esto, con la intención de observar desde una perspectiva intersectorial, la respuesta en la atención del sector salud a las mujeres que han padece violencia por parte de su pareja en México, según la ENDIREH 2011. La metodología y principales resultados de este análisis se presentan en los siguientes apartados.

\section{Descripción de datos y metodología}

El presente trabajo usa los datos de la Encuesta Nacional de la Dinámica de las Relaciones en los Hogares 2011 (ENDIREH, 2011). Esta encuesta contó con tres apartados para a captación de datos: 1) mujeres casadas o unidas; 2) mujeres divorciadas, separadas o viudas, y 3) mujeres solteras. La muestra en total de mujeres casadas y unidas es de 87169 casos $^{2}$. Este estudio se concentró en el primer grupo, mujeres casadas o unidas, mayores de 15 años. Con el fin de observar la incidencia de violencia en la población en la que se centra el estudio, así como el tipo de respuesta que dicha población obtuvo en el sector salud, se construyeron las siguientes variables para el estudio:

Violencia. Esta variable se refiere al porcentaje de mujeres casadas o unidas, que reportaron haber padecido algún tipo de violencia por parte de su pareja. Este porcentaje se obtuvo de la observación de las preguntas 6_1_1 a 6_1_30, en total 30 preguntas del Capítulo VI Relación Actual. A partir de estas preguntas se construyó la variable "Violencia". Si en alguna de estas preguntas la encuestada contestaba "muchas veces", "pocas veces" o "una vez" fue considerada como Mujer que sufre de violencia por parte de su pareja. El promedio fue de $44.6(n=38846)$. En los casos en las que la respuesta fue "No ocurrió" en las 30 preguntas, se consideró como una mujer que no sufrió de violencia por parte de su pareja; el promedio de estos casos fue $55.4(n=48323)$. 


\section{Medrano, Miranda \& Figueras - Violencia de pareja contra las mujeres en México}

Indígena. Esta variable categórica se refiere a la pertenencia a un grupo indígena. Con el fin de identificar la pertenencia de las mujeres encuestadas a un grupo indígena, se tomó la pregunta 1.2 "¿Usted habla alguna lengua indígena?" de la ENDIREH 2011, codificada como AP1_2. Aun cuando ser hablante de una lengua indígena no significa necesariamente pertenecer a un grupo indígena o ser indígena; es el indicador aproximado que generalmente se usa para identificar a la población indígena. La población de mujeres de 15 años y más hablante de lengua indígena en la muestra es de $6.4 \%(\mathrm{n}=5568)$ del total.

Oportunidades. Esta variable identifica si las mujeres encuestadas reciben ayuda del programa social Oportunidades ${ }^{3}$. Este programa se destina a hogares que viven pobreza extrema en México. En este sentido, esta variable sirve es útil como indicador aproximado de la situación de pobreza de las mujeres encuestadas. Para este variable, se utilizó la pregunta 1.4 inciso 5 "Actualmente iusted recibe dinero o apoyo del programa Oportunidades?", de la encuesta de la ENDIREH 2011. La población de mujeres de 15 años y más que recibieron apoyo del programa Oportunidades es de 14.6\% (12738) del total de la muestra.

Servicios médicos. Esta variable se refiere a la institución pública o privada proveedora de servicios médicos a la que acudieron las mujeres que sufrieron violencia y buscaron atención médica. Esta variable se generó a partir de la pregunta 6.19 “¿A dónde acudió la última vez?”, que se refiere a la institución pública o privada proveedora de servicios médicos a la cual reportaron acudir las mujeres encuestadas. Esta variable permite identificar las instituciones de servicios médicos a las cuales han asistido las mujeres mayores de 15 años después de haber padecido un episodio de violencia. Las opciones de esta variable son: médico particular, Cruz Roja, IMSS, ISSSTE, Salubridad, Otro, No especificado.

Maltrato. Esta variable permite identificar si las mujeres encuestadas reportaron algún tipo de maltrato por parte del personal de los organismos de saludos a los que acudieron. Esta variable se generó a partir de las siguientes preguntas específicas que incluye la pregunta 6.20 , ¿ ¿No hicieron nada, no le hicieron caso?" y "¿La humillaron o la trataron mal?". En los casos en los que se contestó de manera afirmativa a alguna de estas preguntas, se consideró que hubo maltrato. 
Trato deficiente. Esta variable permite identificar si las mujeres encuestadas reportaron un trato que se considera ineficiente. Esta variable se generó a partir de las siguientes preguntas específicas que incluye la pregunta 6.20:“¿Indagaron sobre cómo sucedieron las lesiones?”, "Le informaron sobre los servicios psicológicos, médicos y de trabajo social?", “¿Le sugirieron denunciar los hechos ante el ministerio público?”. Estas preguntas se refieren a acciones que, de acuerdo a la normatividad, el personal debería realizar ante los casos de violencia contra mujeres. Así, en los casos en los que se contestó negativamente que afirmativamente o positivamente, según corresponda, a al menos algunas de estas preguntas, se considera que hubo un trato deficiente por parte del sector salud.

Con base en estas dos últimas variables, se identificó el tipo de trato que recibieron las mujeres que acudieron al sector salud, a consecuencia de algún tipo de violencia ejercida en su contra por parte de sus parejas. Así, se realizaron tablas de contingencia con base en estas variables. Estas tablas constituyen una herramienta útil para registrar y analizar la asociación entre dos o más variables, generalmente de tipo cualitativo, como las que se ocupan en este estudio. Los principales resultados se presentan en al siguiente sección.

\section{Resultados}

En general, la proporción de mujeres casadas o unidas que sufren algún tipo de violencia por parte de sus parejas, y que recibieron asistencia médica, es muy reducida. De acuerdo con la ENDIREH 2011, únicamente 3.9\% y $5.8 \%$ de la población mujeres indígena y no indígena, respectivamente, dijo haber asistido al médico a consecuencia de violencia ejercida por parte de sus parejas. Aunque los datos son similares para ambos grupos de mujeres, las que pertenecen a un grupo indígena acuden al médico en menor proporción que las no indígenas. Del total de mujeres consideradas para este estudio, sólo 6.4\% de mujeres hablan una lengua indígena (ENDIREH, 2011). El porcentaje de violencia que se registra entre mujeres indígenas es ligeramente superior $(44.8 \%)$ al de no indígenas $(41.1 \%)$ (ENDIREH, 2011).

En el caso del grupo de mujeres que ocupa este estudio, sólo $2.4 \%$ acudió al sector salud como después de haber sido violentadas. Del total de estas mujeres que buscó atención médica, 25\% acudió a un médico 
1245 Medrano, Miranda \& Figueras - Violencia de pareja contra las mujeres en México

particular; .9\%, a la Cruz Roja; 15.2, al IMSS; 3.9\%, al ISSSTE; 15.8\%, al alguna clínica de la Secretaría de Salud; $38.5 \%$, indicó que acudió a "otro" servicio, y .6\% no especificó a donde se atendió (ver tabla 1). Estos porcentajes varían para los grupos de población indígena y no indígena. La población no indígena acudió en mayor proporción (25.6\%) que la indígena (12.8\%) a un médico particular (ver tabla 1); además, esta última población asistió principalmente a la SSA y, sobre todo, a otro tipo de servicio (32.6\%). Cabe resaltar que, en ambos grupos de población, se reportó "otro" como el servicio más utilizado. No obstante, la ENDIREH 2011 no especifica a qué se refiere la categoría "otros", la cual podría incluir algún servicio de salud de tipo tradicional u otorgado por alguna organización de tipo religioso o caritativo.

Tabla 1

Instituciones de salud en las que se atendieron mujeres indígenas y no indígenas violentadas, 2011.

\begin{tabular}{|l|c|c|c|c|c|c|c|c|}
\hline \multicolumn{1}{|c|}{$\%$} & $\begin{array}{c}\text { Médico } \\
\text { Particular }\end{array}$ & $\begin{array}{c}\text { Cruz } \\
\text { Roja }\end{array}$ & IMSS & ISSSTE & SSA & Otro & NE & Total \\
\hline $\begin{array}{l}\text { No } \\
\text { Indígena }\end{array}$ & 25.6 & .9 & 15.1 & 3.8 & 15.3 & 38.7 & .6 & 100 \\
\hline Indígena & $\mathbf{1 2 . 8}$ & $\mathbf{1 . 2}$ & $\mathbf{1 7 . 4}$ & $\mathbf{7}$ & $\mathbf{2 7 . 9}$ & $\mathbf{3 2 . 6}$ & $\mathbf{1 . 2}$ & $\mathbf{1 0 0}$ \\
\hline Total & 25 & .9 & 15.2 & 3.9 & 15.8 & 38.5 & .6 & 100 \\
\hline
\end{tabular}

Fuente: Elaboración propia con datos de ENDIREH 2011

Estos resultados muestran que hubo deficiencias importantes en la atención a las mujeres que acuden a diferentes organismos de salud, ya que se incumple con algunas de las acciones que contemplan los protocolos de atención, como se mencionó en apartado anterior. Asimismo, se registraron casos de maltrato, $10 \%$ de las mujeres que acudieron al sector salud reportó que no hicieron nada o no le hicieron caso; y una de cien dijo que la humillaron o la trataron mal. Otro hallazgo importante es que la frecuencia con la que se reportan casos de trato ineficiente y maltrato por parte del 
sector salud es similar en los distintos grupos de mujeres que considera este estudio, según condición de pobreza (observada a partir la condición de ser beneficiaria del programa Oportunidades ${ }^{4}$ ) o pertenencia a un grupo indígena ${ }^{5}$ los resultados son similares. Como se puede observar en las tablas 3 y 4, las diferencias entre mujeres indígenas y no indígenas son mínimas, así como entre las mujeres que reciben Oportunidades y las que no son beneficiarias de este programa. 


\section{Medrano, Miranda \& Figueras - Violencia de pareja contra las mujeres en México}

Tabla 2

Trato que recibieron mujeres violentadas en el sector salud, desagregado por grupos, 2011

\begin{tabular}{|c|c|c|c|c|c|c|c|}
\hline & \multirow[b]{2}{*}{ Pregunta } & \multicolumn{2}{|c|}{ Indígena } & \multicolumn{2}{|c|}{ No Indígena } & \multirow{2}{*}{$\begin{array}{c}\text { Pobre } \\
\text { Recibe } \\
\text { Oportunidades }\end{array}$} & \multirow{2}{*}{$\begin{array}{c}\text { No pobre } \\
\text { No Recibe } \\
\text { Oportunidades }\end{array}$} \\
\hline & & $\begin{array}{c}\text { Con } \\
\text { Oportunidades }\end{array}$ & $\begin{array}{c}\text { Sin } \\
\text { Oportunidades }\end{array}$ & $\begin{array}{c}\text { Con } \\
\text { Oportunidades }\end{array}$ & $\begin{array}{c}\text { Sin } \\
\text { Oportunidades }\end{array}$ & & \\
\hline \multirow[b]{2}{*}{$\begin{array}{c}\text { Trato } \\
\text { deficiente }\end{array}$} & $\begin{array}{l}\text { Indagaron } \\
\text { sobre cómo } \\
\text { sucedieron las } \\
\text { lesiones } \\
\text { (Respuestas } \\
\text { afirmativa). }\end{array}$ & 0.20 & 0.18 & 0.17 & 0.16 & 0.17 & 0.16 \\
\hline & $\begin{array}{l}\text { Informaron } \\
\text { sobre los } \\
\text { servicios } \\
\text { psicológicos, } \\
\text { médicos y de } \\
\text { trabajo social } \\
\text { (Respuesta } \\
\text { afirmativa). }\end{array}$ & 0.41 & 0.45 & 0.46 & 0.48 & 0.45 & 0.48 \\
\hline
\end{tabular}


GÉNEROS-Multidisciplinary Journal of Gender Studies, 6(1) 1248

\begin{tabular}{|c|c|c|c|c|c|c|c|}
\hline & $\begin{array}{l}\text { Le sugirieron } \\
\text { denunciar los } \\
\text { hechos ante el } \\
\text { ministerio } \\
\text { público. } \\
\text { (Respuesta } \\
\text { afirmativa). }\end{array}$ & 0.15 & 0.11 & 0.14 & 0.11 & 0.14 & 0.11 \\
\hline \multirow{3}{*}{ Maltrato } & $\begin{array}{l}\text { No hicieron } \\
\text { nada, no le } \\
\text { hicieron caso. }\end{array}$ & 0.10 & 0.11 & 0.11 & 0.10 & 0.11 & 0.10 \\
\hline & $\begin{array}{l}\text { La humillaron } \\
\text { o la trataron } \\
\text { mal. }\end{array}$ & 0.00 & 0.00 & 0.01 & 0.01 & 0.01 & 0.01 \\
\hline & Otro & 0.15 & 0.14 & 0.11 & 0.14 & 0.12 & 0.14 \\
\hline
\end{tabular}

Fuente: Elaboración propia con datos de ENDIREH 2011 


\section{Medrano, Miranda \& Figueras - Violencia de pareja contra las mujeres en México}

Tabla 3

Trato que recibieron mujeres indígenas en diferentes instituciones de salud, 2011.

\begin{tabular}{|c|c|c|c|c|c|c|c|c|c|c|c|c|c|c|c|c|}
\hline & \multicolumn{16}{|c|}{ Indígena } \\
\hline & \multicolumn{8}{|c|}{ Recibe Oportunidades } & \multicolumn{8}{|c|}{ No Recibe Oportunidades } \\
\hline & $\begin{array}{c}\text { Médico } \\
\text { Particular }\end{array}$ & $\begin{array}{l}\text { Cruz } \\
\text { Roja }\end{array}$ & IMSS & ISSSTE & SSA & Otro & & $\begin{array}{c}\% \text { Total } \\
\text { Tipo }\end{array}$ & $\begin{array}{c}\text { Médico } \\
\text { Particular }\end{array}$ & $\begin{array}{l}\text { Cruz } \\
\text { Roja }\end{array}$ & IMSS & ISSSTE & SSA & Otro & & $\begin{array}{c}\text { \% Total } \\
\text { Tipo }\end{array}$ \\
\hline Preguntas & 1 & 2 & 3 & 4 & 5 & 6 & Total & $\begin{array}{c}\text { de } \\
\text { Trato }\end{array}$ & 1 & 2 & 3 & 4 & 5 & 6 & Total & de Trato \\
\hline $\begin{array}{l}\text { ¿Indagaron } \\
\text { sobre cómo } \\
\text { sucedieron } \\
\text { las lesiones? }\end{array}$ & 2 & & 0 & & 5 & 1 & 8 & 0.20 & 4 & 0 & 1 & 2 & 0 & 1 & 8 & 0.18 \\
\hline $\begin{array}{l}\text { ¿Le } \\
\text { informaron } \\
\text { sobre los } \\
\text { servicios } \\
\text { psicológicos, } \\
\text { médicos y de } \\
\text { trabajo } \\
\text { social? }\end{array}$ & 1 & & 5 & & 7 & 4 & 17 & 0.41 & 4 & 0 & 3 & 3 & 3 & 7 & 20 & 0.45 \\
\hline
\end{tabular}


GÉNEROS-Multidisciplinary Journal of Gender Studies, 6(1) 1250

\begin{tabular}{|c|c|c|c|c|c|c|c|c|c|c|c|c|c|c|}
\hline $\begin{array}{l}\text { ¿Le } \\
\text { sugirieron } \\
\text { denunciar los } \\
\text { hechos ante } \\
\text { el ministerio } \\
\text { público? }\end{array}$ & 0 & 0 & 3 & 3 & 6 & 0.15 & 0 & 0 & 1 & 0 & 1 & 3 & 5 & 0.11 \\
\hline $\begin{array}{l}\text { ¿No hicieron } \\
\text { nada, no le } \\
\text { hicieron } \\
\text { caso? }\end{array}$ & 0 & 1 & 1 & 2 & 4 & 0.10 & 0 & 0 & 3 & 1 & 0 & 1 & 5 & 0.11 \\
\hline $\begin{array}{l}\text { ¿La } \\
\text { humillaron o } \\
\text { la trataron } \\
\text { mal? }\end{array}$ & 0 & 0 & 0 & 0 & 0 & 0.00 & 0 & 0 & 0 & 0 & 0 & 0 & $\mathbf{0}$ & 0.00 \\
\hline Otro & 0 & 0 & 4 & 2 & 6 & 0.15 & 0 & 1 & 1 & 0 & 0 & 4 & 6 & 0.14 \\
\hline Total & 3 & 6 & 20 & 12 & 41 & 1.00 & 8 & 1 & 9 & 6 & 4 & 16 & 44 & 1.00 \\
\hline 85 & 41 & & & & & & 44 & & & & & & & \\
\hline
\end{tabular}

Fuente: Elaboración propia con datos de ENDIREH 2011 


\section{Medrano, Miranda \& Figueras - Violencia de pareja contra las mujeres en México}

Tabla 4.

Trato que recibieron mujeres no indígenas en diferentes instituciones de salud, 2011

\begin{tabular}{|c|c|c|c|c|c|c|c|c|c|c|c|c|c|c|c|c|}
\hline & \multicolumn{16}{|c|}{ No Indígena } \\
\hline & \multicolumn{8}{|c|}{ Recibe Oportunidades } & \multicolumn{8}{|c|}{ No Recibe Oportunidades } \\
\hline & $\begin{array}{c}\text { Médico } \\
\text { Particular }\end{array}$ & $\begin{array}{l}\text { Cruz } \\
\text { Roja }\end{array}$ & IMSS & ISSSTE & SSA & Otro & & $\begin{array}{c}\text { \% Total } \\
\text { Tipo }\end{array}$ & $\begin{array}{c}\text { Médico } \\
\text { Particular }\end{array}$ & $\begin{array}{l}\text { Cruz } \\
\text { Roja }\end{array}$ & IMSS & ISSSTE & SSA & Otro & & $\begin{array}{c}\text { \% Total } \\
\text { Tipo }\end{array}$ \\
\hline Preguntas & 1 & 2 & 3 & 4 & 5 & 6 & Total & de Trato & 1 & 2 & 3 & 4 & 5 & 6 & Total & de Trato \\
\hline $\begin{array}{l}\text { ¿Indagaron sobre } \\
\text { cómo sucedieron las } \\
\text { lesiones? }\end{array}$ & 8 & 1 & 4 & 1 & 11 & 19 & 44 & 0.17 & 101 & 4 & 35 & 14 & 34 & 97 & 285 & 0.16 \\
\hline $\begin{array}{l}\text { ¿Le informaron sobre } \\
\text { los servicios } \\
\text { psicológicos, } \\
\text { médicos y de trabajo } \\
\text { social? }\end{array}$ & 13 & 0 & 17 & 0 & 37 & 53 & 120 & 0.46 & 196 & 1 & 123 & 35 & 112 & 370 & 837 & 0.48 \\
\hline $\begin{array}{l}\text { ¿Le sugirieron } \\
\text { denunciar los hechos } \\
\text { ante el ministerio } \\
\text { público? }\end{array}$ & 1 & 0 & 4 & 1 & 7 & 23 & 36 & 0.14 & 39 & 8 & 19 & 9 & 29 & 91 & 195 & 0.11 \\
\hline $\begin{array}{l}\text { ¿No hicieron nada, } \\
\text { no le }\end{array}$ & 10 & 0 & 2 & 0 & 15 & 3 & 30 & 0.11 & 51 & 2 & 53 & 9 & 27 & 30 & 172 & 0.10 \\
\hline
\end{tabular}


GÉNEROS -Multidisciplinary Journal of Gender Studies, 6(1) 1252

\begin{tabular}{|c|c|c|c|c|c|c|c|c|c|c|c|c|c|c|c|c|}
\hline hicieron caso? & & & & & & & & & & & & & & & & \\
\hline $\begin{array}{l}\text { ¿La humillaron o la } \\
\text { trataron mal? }\end{array}$ & 0 & 1 & 1 & 0 & 0 & 0 & 2 & 0.01 & 1 & 0 & 8 & 1 & 5 & 2 & 17 & 0.01 \\
\hline Otro & 4 & 1 & 6 & 0 & 8 & 10 & 29 & 0.11 & 92 & 1 & 35 & 6 & 23 & 83 & 240 & 0.14 \\
\hline Total & 36 & 3 & 34 & 2 & 78 & 108 & 261 & 1.00 & 480 & 16 & 273 & 74 & 230 & 673 & 1746 & 1.00 \\
\hline 85 & 261 & & & & & & & & 1746 & & & & & & & \\
\hline
\end{tabular}

Fuente: Elaboración propia con datos de ENDIREH 2011 


\section{Medrano, Miranda \& Figueras - Violencia de pareja contra las mujeres en México}

\section{Discusión}

El papel que desempeñan las organizaciones de la salud para atender y prevenir violencia contra las mujeres es crucial para solucionar este grave problema social. Por ello, resulta indispensable el escrutinio atento y continúo a la respuesta que, en los hechos, el sector salud brinda a las mujeres que padecen violencia, en toda la cadena de acciones que implica dicha respuesta. En esta línea, este trabajo se centra en el trato que reciben la mujeres casadas o unidas que han padecido violencia en el sector salud, en particular, en lo que refiere a ciertas acciones que se consideran clave para atender y prevenir violencia de manera adecuada, según la normatividad nacional e internacional. Además, este estudio explora las potenciales diferencias en el trato que reciben las mujeres por parte del sector salud, según su estatus socioeconómico y/o pertenencia a un grupo indígena.

Los resultados de esta investigación muestran que hay un problema extendido de atención inadecuada en el sector salud. En general, se observa que no hay diferencias sustantivas en el trato que brindó el sector salud por condición socioeconómica o pertenencia a grupo indígena. En no más de $20 \%$ de los casos, en ambos grupos, se indagó el origen de las lesiones de las mujeres violentadas que acudieron al sector salud. En cuanto a la sugerencia para denunciar los hechos ante el Ministerio Público, el personal que atendió las mujeres sugirió denunciar ante el MP únicamente entre $11 \%$ y $15 \%$ de los casos presentados. Además, el personal del sector salud informó a las mujeres sobre los servicios de apoyo sólo entre 41 y $48 \%$ de los casos atendidos. Finalmente, a una de cada diez mujeres que asistieron al sector salud no le hicieron caso alguno.

En particular, los resultados sugieren deficiencias importantes en la aplicación de protocolos de atención a este grupo vulnerable en el sector salud. Aun cuando los porcentajes relativos a trato deficiente o maltrato son similares en todos los grupos de mujeres violentadas, hay que destacar que las mujeres en condición de pobreza y las mujeres indígenas acuden con mayor frecuencia a los organismos de salud pública, especialmente los pertenecientes a la Secretaría de Salud e IMSS que las mujeres no indígenas. Por tanto, los fallos en lo que puedan incurrir las instituciones de salud pública tienen implicaciones más graves en cuanto que, de facto, son 
prácticamente la única opción de atención para los grupos de población femenina en condiciones sociales más vulnerables.

Otro aspecto que hay que enfatizar es que la mayor proporción de mujeres casadas o unidas, en todos los grupos, que buscaron atención médica optaron por otro tipo de servicios. El uso de ese otro tipo de servicios, cuyas características no se encuentra especificado en la información usada para este estudio (ENDIREH, 2011), puede tener implicaciones negativas para la aplicación de protocolos de violencia a víctimas de violencia, ya que en dichos servicios puede resultar aún más difícil vigilar el cumplimiento de dichos protocolos. Además, el uso de otros servicios puede reflejar un problema no sólo de falta de acceso a las instituciones de salud por parte de las mujeres que padecen violencia, sino que, en el caso de que dicho acceso sea efectivo, se prefiera no hacer uso de las mismas por deficiencias en la atención que brindan. De esta forma, se crea un círculo vicioso por la incapacidad de las organizaciones de salud para brindar servicios adecuados.

También es importante considerar que, en principio, las mujeres que padecen violencia y acuden al médico, especialmente las que están en condiciones sociales más vulnerables, pueden tener elementos o incentivos reportar deficiencias o, incluso, maltrato por parte del sector salud. Por ejemplo, las mujeres que son beneficiarias del Programa Oportunidades y, que, en consecuencia, tienen como opción acudir a las clínicas del IMSS o de la Secretaría de Salud, ya que, como parte del programa se les requiere cumplir con cierto número de visitas médicas, pueden tener ciertas reticencias para denunciar deficiencias o maltrato por parte del personal de tales instituciones de salud. Además, los datos utilizados para el estudio, la ENDIREH 2011, comparte las limitaciones que este tipo de encuestas enfrentan para recabar información de un tema difícil y sensible, del cual incluso las propias víctimas no necesariamente están en condiciones de identificar de la mejor forma. No obstante, a pesar de estas limitaciones, este estudio pone énfasis en que es indispensable conocer las diferencias en el trato que se presentan no sólo por las diferencias particulares de ciertos grupos de población femenina que padece violencia, sino por el tipo de instituciones de salud que atiende esta población.

Finalmente, como se reconoció nacional e internacionalmente, el sector salud es clave para garantizar una atención y prevención de la violencia 


\section{Medrano, Miranda \& Figueras - Violencia de pareja contra las mujeres en México}

contra mujeres, es urgente profundizar más sobre las causas que originan los deficiencias de atención para cada uno de las diferentes organizaciones del sector salud, en el ámbito público y privado. Además, hay que indagar más sobre el trato que se brinda a mujeres en las otras instancias en las que ellas buscan apoyo ante episodios de violencia. De tal forma que se puedan diseñar soluciones para atender las deficiencias en el corto y largo plazo.

\section{Conclusiones}

En este trabajo se analizó, desde una perspectiva interseccional, las diferencias en el trato que las mujeres víctimas de violencia pueden obtener por parte del sector salud, según su estatus socioeconómico (situación de beneficiaria del programa Oportunidades, que se puede considerar un indicador aproximado a condición de pobreza extrema) y pertenencia a un grupo indígena. En línea con otros estudios, este trabajo aporta evidencia de que hay un problema grave de atención inadecuada en el sector salud. En general, los resultados de este estudio sugieren que no hay diferencias sustantivas en el trato que reciben las mujeres violentadas, según su condición socioeconómica o pertenencia a grupo indígena. Los porcentajes relativos a trato deficiente o maltrato son similares en todos los grupos. En este sentido, los datos agregados sugieren que las mujeres más pobres o indígenas no necesariamente padecen maltratos en mayor proporción que las mujeres menos pobres o no indígenas. Es decir, las deficiencias en el trato, así como el maltrato, por parte del sector salud en generalizado.

No obstante, el estudio permitió observar que distintos grupos de población femenina que padece violencia acude a diferentes organizaciones de salud. Las mujeres indígenas y pobres tienen como principal opción, además de otros servicios que no se ubican en el sector salud tradicional, los hospitales de la Secretaría de Salud e IMSS-Oportunidades. En consecuencia, las deficiencias de estas organizaciones de salud afectan más comparativamente a estos sectores de la población que otros que tienen otras opciones de atención. Este estudio también puso en evidencia que una proporción importante de mujeres acude a otros servicios que no están incluidos en el sector público, presumiblemente de medicina tradicional o servicios que pueden prestar organizaciones del sector civil. El hecho de que las mujeres no tengan acceso real a servicios del sector salud, o que, 
por alguna razón, prefieran no usarlos significa, en principio, un fallo del dicho sector para brindar servicios de atención y prevención de la violencia.

El personal del sector salud tiene responsabilidad directa en distintas acciones cruciales para las víctimas, tales como la detección del problema, proporcionar tratamiento médico, brindar apoyo emocional y psicológico, canalizar para distintos apoyos de asistencia social, brindar acompañamiento y seguimiento para denunciar los hechos ante las instancias pertinentes. Por ello, las deficiencias en alguna de estas acciones por parte del personal de salud ante casos de violencia contra las mujeres denotan fallas en el sistema en su conjunto. En consecuencia, resulta indispensable conocer la forma en que el sector salud está poniendo en práctica las acciones que, al menos normativamente, le corresponden para atender y prevenir la violencia contra mujeres. Para tener un mejor conocimiento de lo anterior, el enfoque interseccional es una herramienta útil para observar las diferencias en la respuesta del sector salud a distintos grupos de mujeres que padecen violencia en México. Este conocimiento puede arrojar luz para entender por qué la persistencia y magnitud del problema de violencia contra mujeres en ámbito doméstico, a pesar de la existencia de políticas de atención y prevención dirigidas a este problema.

\section{Notas}

${ }^{1}$ Política de Desarrollo Social (CONEVAL), la población en pobreza se refiere a aquellas personas que tienen al menos una carencia a derechos sociales (educación, salud, seguridad social, vivienda, servicios básicos, alimentación) y que su ingreso sea menor a la línea de bienestar ( $\$ 2,542.13$ zonas urbanas y $\$ 1,614.65$ en zonas rurales).

${ }^{2}$ El cuestionario general se conformó de 17 secciones temáticas. Las primeras tres secciones muestran datos sociodemográficos; la cuarta sección verifica el estado conyugal, mientras que las otras 13 secciones se refieren a cómo sucede la violencia en distintos espacios de convivencia públicos y privados. La encuesta se aplicó a mujeres de 15 años y más residentes de las viviendas seleccionadas entre el 3 de octubre y el 11 de noviembre de 2011, con una cobertura nacional y con representación nacional en zonas urbanas y rurales, y estatal. El diseño de la muestra fue probabilístico, estratificado.

${ }^{3}$ El gobierno federal puso en práctica el Programa de Educación, Salud y Alimentación (Progresa) en 1997, el cual se renombró Programa de Desarrollo Humano Oportunidades, Oportunidades, en 2002. (Desde 2014, este programa se denomina Programa de Inclusión Social PROSPERA). Este programa federal es el principal programa de transferencias monetarias condicionadas de México, y se dirige a los hogares en situación de pobreza extrema. Para que los hogares puedan ser elegibles, se utiliza una prueba aproximada de medios (es decir, se le pide comprobar su situación de pobreza extrema) con base en la información recogida a través de la Encuesta de Características Socioeconómicas y Demográficas de los Hogares (ENCASEH), la cual un responsable de cada hogar debe 


\section{Medrano, Miranda \& Figueras - Violencia de pareja contra las mujeres en México}

responder. Es decir, los integrantes de las familias que reciben este programa se consideran en situación de pobreza extrema.

${ }^{4}$ Para obtener los porcentajes de mujeres casadas, violentadas, mayores de 15 años, que recibieron o no el Programa Oportunidades y reportaron ir a algún Servicio Médico el último año a causa de violencia por Trato de la Institución se cruzaron las variables 1.4 referente a haber recibido el Programa Oportunidades, ap6_19 referente a la Institución de Servicio Médico a la que acudió y 6_20 referente al Trato que se le dio en la Institución de Salud. De éste cruce se obtuvo un total de 2092 casos $(2.4 \%)$, de los cuales $14.4 \%(\mathrm{n}=302)$ de los casos fueron de mujeres que reciben el Programa Oportunidades y el $85.6(n=1790)$ de los casos son de mujeres que no Reciben el Programa Oportunidades.

${ }^{5}$ Para obtener los porcentajes de mujeres casadas, violentadas, mayores de 15 años, que hablan o no alguna lengua indígena y reportaron ir a algún Servicio Médico el último año a causa de violencia por Trato de la Institución se cruzaron las variables 1.2 referente a hablar alguna lengua indígena, ap6_19 referente a la Institución de Servicio Médico a la que acudió y 6_20 referente al Trato que se le dio en la Institución de Salud. De este cruce se obtuvo un total de 2536 casos $(2.9 \%)$, de los cuales $95.6 \%(n=2425)$ de los casos son mujeres que no hablan ninguna lengua indígena y el $4.4 \%(\mathrm{n}=111)$ de los casos son mujeres que hablan alguna lengua indígena. 


\section{Referencias}

Agoff, C., Rajsbaum, A. \& Herrera, C. (2006). Perspectivas de las mujeres maltratadas sobre la violencia de pareja en México. Salud Pública De México, s307. doi:10.1590/s0036-36342006000800011

Bent-Goodley, T. B. (2004). Perceptions of domestic violence: A dialogue with African American women. Health \& Social Work, 29(4), 307-316.

Burman, E., \& Chantler, K. (2005). Domestic violence and minoritisation: legal and policy barriers facing minoritized women leaving violent relationships. International journal of law and psychiatry, 28(1), 59-74.

Cha, S., \& Masho, S. W. (2014). Discussions about intimate partner violence during prenatal care in the United States: The role of race/ethnicity and insurance status. Maternal and child health journal, 18(6), 1413-1422.

Chang, J. C., Cluss, P. A., Ranieri, L., Hawker, L., Buranosky, R., Dado, D., ... \& Scholle, S. H. (2005). Health care interventions for intimate partner violence: what women want. Women's Health Issues, 15(1), 21-30.

Colombini, M., Mayhew, S., \& Watts, C. (2008). Health-sector responses to intimate partner violence in low-and middle-income settings: a review of current models, challenges and opportunities. Bulletin of the World health Organization,86(8), 635-642.

Consejo Nacional de Evaluación de la Política de Desarrollo Social. (2015). Medición de la pobreza en México y en las entidades federativas 2014. Recuperado de http://www.coneval.org.mx/Medicion/Documents/Pobreza\%202014_CO NEVAL_web.pdfModelo Integrado para la prevención y atención de la violencia familiar y sexual MIPAVF (2009).

Conwill, W. L. (2010). Domestic violence among the Black poor: Intersectionality and social justice. International Journal for the Advancement of Counselling,32(1), 31-45.

Estrada, C. \& Rodríguez, F. (2011). Violencia y temor por la vida en mujeres jaliscienses violentadas por su pareja íntima. Revista Cubana De Salud Pública, (4), 462.

Ellsberg, M., Arango, D. J., Morton, M., Gennari, F., Kiplesund, S., Contreras, M., \& Watts, C. (2015). Prevention of violence against women and girls: what does the evidence say?. The Lancet, 385(9977), 15551566. 
Goicolea, I., Hurtig, A. K., San Sebastian, M., Vives-Cases, C., \& Marchal, B. (2015). Developing a programme theory to explain how primary health care teams learn to respond to intimate partner violence: a realist case-study. BMC health services research, 15(1), 228.

Gómez-Dantés, H., Vázquez-Martínez, J. L., \& Fernández-Cantón, S. B. (2006). La violencia en las mujeres usuarias de los servicios de salud en el IMSS y la SSA. Salud Pública De México, 48S279-S287

Herrera, C. \& Agoff C. (2006). Dilemas del personal médico ante la violencia de pareja en México. Cadernos De Saúde Pública, (11), 2349.

Herrera, C., Rajsbaum, A., Agoff, C. \& Franco, A. (2006). Entre la negación y la impotencia: prestadores de servicios de salud ante la violencia contra las mujeres en México. Salud Pública De México, s259. doi:10.1590/s0036-36342006000800006

Herrera, C. M. (2013). Marchas y contramarchas en la atención de la violencia contra las mujeres en las instituciones de salud mexicanas. Estudios Sociológicos, 21-37.

Híjar, M., Avila-Burgos, L., \& Valdez-Santiago, R. (2006). ¿Cuándo utilizan servicios de salud las mujeres que viven en condiciones de violencia de pareja?. Salud Mental, 29(6), 57-64.

Hill, N. A., Woodson, K. M., Ferguson, A. D., \& Parks Jr, C. W. (2012). Intimate partner abuse among African American lesbians: Prevalence, risk factors, theory, and resilience. Journal of Family Violence, 27(5), 401-413.

Houston, P., Muñoz, A., Heberlein, E., \& Alvarado, N. (2010). Violencia intrafamiliar (VIF) Quinchao, Chiloé (Chile). Cuad Méd Soc. (Chile), 50(4), 315-321.

Instituto Nacional de Estadística y Geografía, INEGI. (2011). Encuesta Nacional sobre la Dinámica de las Relaciones en los Hogares. Recuperado de: http://www3.inegi.org.mx/sistemas/biblioteca/ficha.aspx?upc=70282505 1266

Josephson, J. (2002). The intersectionality of domestic violence and welfare in the lives of poor women. Journal of Poverty, 6(1), 1-20. 
Koenig, M. A., Ahmed, S., Hossain, M. B., \& Mozumder, A. K. A. (2003). Women's status and domestic violence in rural Bangladesh: individualand community-level effects. Demography, 40(2), 269-288.

McGrath, M. E., Bettacchi, A., Duffy, S. J., Peipert, J. F., Becker, B. M., \& Angelo, L. S. (1997). Violence against women: provider barriers to intervention in emergency departments. Academic Emergency Medicine, 4(4), 297-300.

Méndez-Hernández, P., Valdez-Santiago, R., Viniegra-Velázquez, L., Rivera-Rivera L. \& Salmerón-Castro, J. (2003). Violencia contra la mujer: conocimiento y actitud del personal médico del Instituto Mexicano del Seguro Social, Morelos, México. Salud Pública De México, (6), 473. doi:10.1590/s0036-36342003000600007

Pitt, K. A. (2008). Intersectionallity, Gender and Race lin Women's Experiences of Domestic Violence: Applications to Postcolonial Trinidad. Caribbean Journal of Social Work, Vol. 6/7, pp. 58-82.

Plichta, S. B. (2007). Interactions between victims of intimate partner violence against women and the health care system policy and practice implications. Trauma, Violence, \& Abuse, 8(2), 226-239.

Ruiz-Pérez, I., Blanco-Prieto, P., \& Vives-Cases, C. (2004). Violencia contra la mujer en la pareja: determinantes y respuestas sociosanitarias. Gaceta sanitaria, 18, 4-12.

Secretaría de Salud del Gobierno Federal de los Estados Unidos Mexicanos. (2009). Norma Oficial Mexicana NOM-046-SSA2-2005. Violencia familiar, sexual y contra las mujeres. Criterios para la prevención y atención. Recuperado de http://www.inm.gob.mx/static/Autorizacion_Protocolos/SSA/Violencia_f amiliar_sexual_y_contra_las_mujeres_criterios_par.pdf

Sokoloff, N. J., \& Dupont, I. (2005). Domestic violence at the intersections of race, class, and gender challenges and contributions to understanding violence against marginalized women in diverse communities. Violence against women,11(1), 38-64.

Taket, A., Nurse, J., Smith, K., Watson, J., Shakespeare, J., Lavis, V., ... \& Geder, G. (2003). Routinely asking women about domestic violence in health settings. BMJ: British medical journal, 327(7416), 673-676. 
1261 Medrano, Miranda \& Figueras - Violencia de pareja contra las mujeres en México

Tiburcio, M., Natera, G., \& Berenzon, S. (2010). Utilización de servicios de atención a la salud mental en mujeres víctimas de violencia conyugal. Salud Mental, 33(3), 243-248.

Tower, M. (2007). Intimate partner violence and the health care response: a postmodern critique. Health care for women international, 28(5), 438452.

ONU Mujeres (2015) Infografía: Violencia contra las mujeres. Retrived from http://www.unwomen.org/es/digitallibrary/multimedia/2015/11/infographic-violence-against-women

Valdez-Santiago, R., Juárez-Ramírez, C., Salgado-de Snyder, V. N., Agoff, C., Avila-Burgos, L., \& Híjar, M. C. (2006). Violencia de género y otros factores asociados a la salud emocional de las usuarias del sector salud en México.salud pública de méxico, 48, s250-s258.

Venegas, U., Muñoz, E., Navarro, A., Nuño, L., \& Navarro, C. (2007). Violencia contra la mujer y medicina familiar. Ginecología Y Obstetricia De México, 75(7), 373-378.

Waalen, J., Goodwin, M. M., Spitz, A. M., Petersen, R., \& Saltzman, L. E. (2000). Screening for intimate partner violence by health care providers: barriers and interventions. American journal of preventive medicine, 19(4), 230-237.

World Health Organization. (2013) Global and regional estimates of violence against women: prevalence and health effects of intimate partner violence and non-partner sexual violence. Retrived from http://www.who.int/reproductivehealth/publications/violence/978924156 $4625 /$ en 
GÉNEROS -Multidisciplinary Journal of Gender Studies, 6(1) 1262

\section{Anahely Medrano, Researcher CONACyT-BUAP \\ Martha Miranda, Researcher BUAP \\ Victor Manuel Figueras, Researcher BUAP \\ Contact address: \\ Instituto de Ciencias de Gobierno y Desarrollo Estratégico. \\ Benemérita Universidad Autónoma de Puebla \\ Av. Cúmulo de Virgo s/n. Acceso 4, CCU. Puebla, Puebla \\ C.P. 72810 . México.}

E-mail address: anahely.medrano@correo.buap.mx;

martha.miranda@correo.buap.mx; victor.figueras@correo.buap.mx 


\section{Géneros}

Multidisciplinary Journal of Gender: Studies

\section{Hipatia Press \\ www.hipatiapress.com}

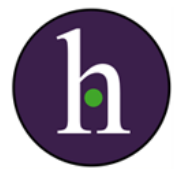

Instructions for authors, subscriptions and further details:

http://generos.hipatiapress.com

\section{Employment, Motherhood and Wellbeing: A Discourse on the Trio within Public Organisations in Southwest Nigeria}

Babatunde Joshua Omotosho ${ }^{1}$

1) Federal University Oye-Ekiti. Nigeria

Date of publication: February $25^{\text {th }}, 2017$

Edition period: February - June 2017

To cite this article: Omotosho, B.J. (2017). Employment, Motherhood and Wellbeing: A Discourse on the Trio within Public Organisations in Southwest Nigeria. Multidisciplinary Journal of Gender Studies, 6(1), 1263-1287. doi: 10.4471/generos.2017.2223

To link this article: http://dx.doi.org/10.4471/generos.2017.2223

\section{PLEASE SCROLL DOWN FOR ARTICLE}

The terms and conditions of use are related to the Open Journal System and to Creative Commons Attribution License (CC-BY). 


\section{Employment, Motherhood and Wellbeing: A Discourse on the Trio within Public Organisations in Southwest Nigeria}

Babatunde Omotosho

Federal University Oye-Ekiti

\section{Abstract}

African women in public service experience some issues in their bid to juggle between their jobs and parenting; however, not much is available within the literature to explain these dynamics. This study seeks to document this by understand their experiences, the coping strategies adopted and the implications on the respondents' wellbeing and that of their children. For quantitative data, a total number of one hundred and sixty questionnaires were purposively administered to mothers with infants working within the selected organizations and complemented with twenty in-depth interview schedules. Findings: a majority ( 40.0 percent) of the respondents were aged 31-40 years. About 73.0 percent claimed their challenges include how to combine paid employment with motherhood while 26.9 percent attributed it to finance. Respondents mentioned that their children experience diarrhoea and malaria (22.2 percent), loss of appetite and weakness (23.1 percent) while they are away to work. On the part of the mothers, 62.3 percent claimed that their major challenges are stress and in ability to focus on their work. Respondents further argued that child spacing (7.5 percent) and support from husband (17.5 percent) are part of their coping mechanisms. Working mothers need a more conducive atmosphere for career development and parenting.

Keywords: woman, motherhood, child, Nigeria, employment 


\section{Empleo, maternidad y bienestar: un discurso sobre el trío dentro de las organizaciones públicas en el suroeste de Nigeria}

Babatunde Omotosho

Federal University Oye-Ekiti

\section{Resumen}

Las mujeres africanas en el servicio público experimentan problemas en su intento de combinar sus trabajos con la crianza de los hijos; Sin embargo, no hay mucha literatura disponible para explicar esta dinámica. Este estudio pretende documentarlo mediante la comprensión de sus experiencias, las estrategias adoptadas y sus implicaciones en el bienestar de las encuestadas y en el de sus hijos. Para los datos cuantitativos, un total de ciento sesenta cuestionarios fueron intencionalmente administrados a madres con niños, que trabajan dentro de las organizaciones seleccionadas, y complementadas con veinte entrevistas en profundidad. Conclusiones: la mayoría (40\%) de las encuestadas tenían entre 31 y 40 años. Cerca de $73 \%$ afirmó que sus desafíos incluyen cómo combinar el empleo remunerado con la maternidad, mientras que $26.9 \%$ los atribuyó a la financiación. Las entrevistadas mencionaron que sus hijos experimentan diarrea y malaria (22.2\%), pérdida de apetito y debilidad (23.1\%) mientras ellas están ausentes para trabajar. Por parte de las madres, el 62,3\% afirmó que sus principales desafíos son el estrés y la capacidad de centrarse en su trabajo. Las encuestadas argumentaron además que el distanciamiento de los hijos (7,5\%) y el apoyo del marido (17,5\%) son parte de sus estrategias. Las madres trabajadoras necesitan un ambiente más propicio para el desarrollo profesional y la crianza de los hijos.

Palabras clave: mujeres, maternidad, hijo, Nigeria, empleo 



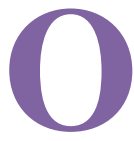

ne of the variants of modernisation includes the involvement of women in paid employment. This development implies that women who over time were full housewives and mothers had to divide their time between paid employment and family care. This has implications on the family structure, child health and development (Basu, 1992). In the last 40 years, women involvement in labour force has increased dramatically across the globe (Hielman and Okimoto, 2008). Notwithstanding and comparatively, mothers face stiffer challenges than women that are yet to give birth (Hielman and Okimoto, 2008). The impact of this situation on the social, psychological and physiological conditions of these mothers cannot be overemphasized. Correll, Bernard and Park, (2007); Gungor and Biernat, (2009) while investigating the dynamics of employment on mothers emphasized that the rigors surrounding work often undermine the competence of mothers in their chosen fields. Aside these, the economic impact on the mothers have been found to be enormous. Budig and England (2001) for instance in their study found out that employed mothers in the United States on average experience a five percent wage penalty per child after controlling other factors that affect earnings. Ridgeway and Correll (2004) also looked at the social label placed on women as being unable to do the expected job based on the assumption that she is a nursing mother, the belief is that a mother is unable to do the normal working hours due to her status as a mother even in situations where the employed mother is discharging her duty effectively. Aside the above, the issue of glass ceiling is also a strong factor affecting these mothers, a situation whereby women based on social factors are not allowed to rise to their desired status. Some of the reasons often associated with this include the perception that they are too feminine and as a result of that they are often perceived as not qualified and competent enough because they are nursing women and if they choose not to be feminine, they regard them as lacking social skills expected of a woman (William, 1992).

This situation is same in Africa and Nigeria is not left out. While studies on the conditions of mothers within work place are scanty, available ones suggest that juggling between work and child care is a challenge to them. Evidence available regarding the plight of women within the workplace still suggests marginalization, unpleasant polices against women and the rest. 
Women constitute 45 percent of the estimated 150 million populations in Nigeria, yet their involvement in leadership positions is not proportionate to their population. Mothers in private organizations do not enjoy the compulsory 3 months' maternity leave especially in private organizations; those working in cities struggle with the demands of urban centres and quite a number of them suffer cultural injustices in within the work environments (Sun news, 2013). Beyond that, the cultural limitations placed on women due to patriarchy also constitute a challenge for working mothers; quite a majority of them have to combine domestic chores with office work and child care. Evidence further suggests that the current situation may worsen (Hein and Cassirer, 2010; Leslie, 1989). The impact of this marginalization on the children cannot be ignored as well. Studies have revealed that the kind of provision for child care in developing countries has failed to meet the present needs of mothers and children (Hein and Cassirer, 2010; Leslie, 1989; Joekes, 1989). The long and short run implication of inadequate child care is high; failure to pay adequate attention to child care from the beginning may expose these children to a number of challenges ranging from malnutrition stress unemployment, increased poverty and among others. Going by these developments, investigating the dynamics of motherhood workplace vis-à-vis mothers and child wellbeing thus becomes critical.

Studies have showed that women form almost half of the total workforce and the figure is expected to rise sharply at the first half of the 21st century (Falzon, 2007; Orr, 1997). Further, it is an established fact that women workers are an essential part of the work system and cannot be dispensed with in any way (Barnett, Marshall \& Sayer, 1992). However, in spite of their uniqueness and qualities, women still suffer challenges due to a combination of work and child care. For instance, Hoffman (1963) observed in his study that work stress has an influence on the quality of the parent-child interaction. Falzon (2007) equally submitted that 78.0 percent of working women still come back home to look after their children when they close from work. The implication of this is that mothers combine two jobs at the same time- a paid employee and a nursing mother. The children are not left out of this encounter; studies reveal that lack of contact between children and parents was directly responsible for the rising levels of mental health problems, sleep disorders and other socio-psychological issues others 
(Falzon, 2007). Ammaniti, et al (2004) also saw that separating children from their parents store up behavioural difficulties for them. These myriads of events within these spaces suggest an investigation of the methods and strategies adopted by mothers to meet the demands of workplace and child care. Further, an assessment of these strategies in relation to the health and welbeing of the child also becomes necessary in this study.

Within the literature, combining the roles of motherhood and work has been regarded as a combination of multiple roles and it has not attracted the required attention. Mothers working outside the home often find it challenging to combine health responsibilities and employment demands, more especially among low income women (Kaiser Family Foundation, 2003). Examining dynamics of motherhood, workplace and child care thus becomes important as one of the means to further throw light to these issues and with the aim of finding lasting solution to some of the challenges women face as mothers within the work places.

The following are the research questions formulated for the study:

\section{Research Questions}

a) What are the socio-economic and demographic characteristics of the respondents?

b) What are the coping strategies adopted in combining motherhood and employment?

c) What are the challenges they face in combining motherhood and employment?

d) What are its implication on their health and that of their child?

The following are the objectives of the study:

\section{Objectives of the Study}

The general objective of the study was to examine the experiences of working mothers to work, motherhood and wellbeing in public organisations in Southwest Nigeria. 
The specific objectives were to:
a) Examine the socio-economic and demographic characteristics of the respondents
b) Understand the challenges respondents face in combining motherhood and employment.
c) Assess its implication on the mother and child's health and wellbeing
d) Assess the coping strategies of the respondent in combining motherhood and employment

\section{Brief Literature review}

\section{Women, work and child care: a brief discourse}

The dynamics of motherhood and work may not be strange in Africa and Nigeria in specific. From pre-colonial through colonial era, women have engaged in different forms of work as a means of survival and as part of their contributions to the maintenance of the family. Women were farmers, traders and some have in the process extended their trade beyond their localities (Omoruyi, 1994).

In some cultures, in Nigeria for instance, some women were found to have excelled in their chosen careers more than their male counterparts. They were able to successfully combine their jobs with child care based on the flexibilities of their jobs. As a matter of fact, in traditional African settings, caring for the children was never a challenge to working mothers basically because the nature of their jobs permitted that. Aside this, the communal lifestyle as reflected in social and housing structure in traditional African societies permitted working mothers to leave their children with the older children if available, or elderly women within the homestead who could no longer do strenuous activities. Thus, children within a particular homestead belonged to all members of that homestead and would be cared for by all. However, with the emergence of paid employment and industrialization in Nigeria, there was a breakdown of this lifestyle such that nuclear families became separated from the extended families. However, the patterns of work changed drastically about fifty years back due to industrialization such that work became more formalized (ILO, 
2010; Chete, Adeoti, Adeyinka and Ogundele, 2014). This development in the country no doubt is an extension of what obtained in developed countries. The developing countries are gradually modelling its work and family patterns after the west yet, the structures needed to make this work has not been successfully put in place. ILO (2010), while explaining the differences at the regional and sub regional levels among developing countries argues that between 1950 and 1985, the proportion of women aged 15 or older in the paid labor force rose from 37 to 42 percent. This of course represents a fraction of women in labor participation as larger percentage of women in Sub Saharan Africa is engaged in informal employments. Notwithstanding, the percentage of economically active women is high, but it appears to have actually declined from slightly above to slightly below 50 percent in the period since 1970 (ILO, 2010).

Joekes (1989) categorized the sources of non-maternal child care into four areas; the first she referred to as 'non-existent' child care which to her is the most frequent child care practice adopted globally. This arrangement is such that children are left unattended to when mothers are busy. The second type has to do with the child care being provided for by members of the household, especially by older siblings. The third type of child care plan relates to exchange of child care among family members and neighbors usually without any financial obligation attached to such exchange of services. The fourth which is the last relates to child care being handled by professionals whether at the formal or informal level for a fee. Joekes (1989) typology provides a description of child care across the globe and as a matter of fact almost all of them are practiced in this part of the globe. The second and the fourth child care plans are however very common among nursing mothers in Nigeria. The reason is simple, they are most times far from their extended families and they need to be close to their children and the demands of modernization are also very important.

\section{Methods}

A total of one hundred and sixty female working mothers were selected from government establishment in Ado Ekiti, the state capital of Ekiti state through a purposive sampling technique over nine major ministries across the government secretariat. By working mothers, we refer to mothers having children between ages 3 months and 2 years. The reason for this 
sampling procedure was because of the nature of the research, which had to look for working mothers within the work setting. In eliciting data from the respondent, the study employed both quantitative and qualitative methods. Questionnaires containing open ended and closed-ended questions were used. Qualitative data involved the use of in-depth interview to capture deeper meanings and insights into the research. A total number of twenty respondents were selected for the in-depth interview. Both quantitative and qualitative data were analyzed accordingly. The questionnaires were analyzed through Statistical Package for Social Science (SPSS) software while the in-depth interview was analyzed and quoted where necessary to support the data from questionnaire. Three hypotheses were tested for this study. They are listed below in alternate forms; chi-square statistical technique was used to identify the direction of the relationship:

1. There is a significant relationship between age and finding parenting and employment easy.

2. There is a significant relationship between marital status and finding parenting and employment easy.

3. Respondents who give in their best to work often find motherhood and employment an easy task

\section{Result Findings}

This section (see Table 1) explains the percentage distribution of respondents' age, education, marital status and professional qualification. Findings on age revealed that respondents between age 31 and 40 dominated the study constituting 40.0 percent. The least were respondents aged 20 and below (10.0 percent). This may not be strange considering the requirements as regards entry into labour force. This is further reflected on the respondents' educational qualification as respondents with tertiary education and professional qualification formed the majority with 32.5 percent and 42.5 respectively. Findings on the marital status also revealed that a majority of the respondents were married. 
1271 Omotosho - Employment, Motherhood and Wellbeing

Table 1

Percentage Distribution of Respondents Based on Selected Socio-Economic Variables

\begin{tabular}{|l|l|l|}
\hline Age & Frequency & Percentage \\
\hline Below 20 years & 16 & 10.0 \\
\hline $21-30$ years & 28 & 17.5 \\
\hline $31-40$ years & 64 & 40.0 \\
\hline 41 and above & 52 & 32.5 \\
\hline Total & 160 & 100.0 \\
\hline Education & Frequency & Percentage \\
\hline Primary & 8 & 5.0 \\
\hline Secondary & 32 & 20.0 \\
\hline Tertiary & 52 & 32.5 \\
\hline Professional qualification & 68 & 42.5 \\
\hline Total & 160 & 100.0 \\
\hline Marital status & Frequency & Percentage \\
\hline Married & 136 & 85.0 \\
\hline Separated/divorced & 24 & 15.0 \\
\hline Total & 160 & 100.0 \\
\hline & & \\
\hline
\end{tabular}

From the table (see Table 2), majority of the respondents earn between 20000 and 40000 in a month; this of course may be a reflection of the salary structure in the country. Aside that, quite a number of them from indepth and questionnaire have spent between 1 and 5 years in the organization. Equally, a total of 9 departments (ministries) were involved in the study with Women Affairs constituting 17.5 percent.

Table 2:

Percentage Distribution of Respondents Based Income and Departments

\begin{tabular}{|l|l|l|}
\hline Income & Frequency & Percentage \\
\hline$*{ }^{1}$ Below 20,000 & 12 & 7.5 \\
\hline $20,001-30000$ & 60 & 37.5 \\
\hline $30001-40000$ & 56 & 35 \\
\hline 40,001 and above & 32 & 20 \\
\hline Total & 160 & 100.0 \\
\hline
\end{tabular}

${ }^{1}$ As at the time of the research, 1 US dollar was equivalent to 160 Nigeria Naira 


\begin{tabular}{|l|l|l|}
\hline Department & Frequency & Percentage \\
\hline Health & 12 & 7.5 \\
\hline Justice & 8 & 5 \\
\hline Lands and Environment & 28 & 17.5 \\
\hline Women Affairs & 28 & 17.5 \\
\hline $\begin{array}{l}\text { Commerce Industry and } \\
\text { Cooperative }\end{array}$ & 16 & 10.0 \\
\hline $\begin{array}{l}\text { Information and Civic } \\
\text { Orientation }\end{array}$ & 20 & 12.5 \\
\hline $\begin{array}{l}\text { Agriculture and Natural } \\
\text { Resources }\end{array}$ & 16 & 10.0 \\
\hline Education and Technology & 16 & 10.0 \\
\hline Establishment and Training & 16 & 10.0 \\
\hline Total & 160 & 100.0 \\
\hline
\end{tabular}

The respondents (see Table 3) were asked to assess whether they are able to give in their best to their work place as mothers, and a majority of the respondents submitted in the affirmative. A number of reasons were given by the respondents as responsible for their responses. They submitted that they come to work as at when due (45.9 percent) and do all tasks assigned to them (54.1 percent). Only 8.8 percent of the respondents felt they were not doing enough for working moms. The major reasons given attributed to this included inability to attend trainings and seminars that can further equip them (42.9 percent) and the opinion that they could perform better than they are doing at the moment (57.1 percent). Hakim (1997) argues one of the determinants for how much to work is often based on sex role attitudes; other studies have also added intentions as key determinants of how much an individual will put into his or her work (Kan 2007; Blozendahl and Myers, 2004). Charles and Harris (2007) summed up the whole argument by emphasizing on the tradition of wanting to do what is right as a strong determinant of putting in the best to work. This tradition of course may propel young mothers to wanting to excel in both work and parenting. 
1273 Omotosho - Employment, Motherhood and Wellbeing

Table 3

Percentage Distribution on Respondent Satisfaction with their Work Performance

\begin{tabular}{|l|l|l|}
\hline $\begin{array}{l}\text { Do you think you are } \\
\text { giving your best to work } \\
\text { as mother? }\end{array}$ & Frequency & Percentage \\
\hline Yes & 146 & 91.2 \\
\hline No & 14 & 8.8 \\
\hline Total & 160 & 100.0 \\
\hline $\begin{array}{l}\text { If yes, why do you think } \\
\text { so }\end{array}$ & Frequency & Percentage \\
\hline $\begin{array}{l}\text { I am always available at } \\
\text { work }\end{array}$ & 67 & 45.9 \\
\hline $\begin{array}{l}\text { I do all that is assigned to } \\
\text { me }\end{array}$ & 79 & 54.1 \\
\hline Total & 146 & 100.0 \\
\hline If no, why not? & Frequency & Percentage \\
\hline $\begin{array}{l}\text { I believe I can do better } \\
\text { than my present } \\
\text { performance }\end{array}$ & 8 & 57.1 \\
\hline $\begin{array}{l}\text { I can't go for training and } \\
\text { seminars }\end{array}$ & 6 & 42.9 \\
\hline Total & 14 & 100.0 \\
\hline
\end{tabular}

This section (see Table 4) examines how the respondents are able to combine motherhood with their jobs.

Table 4

Percentage Distribution on combining motherhood with employment

\begin{tabular}{|l|l|l|}
\hline $\begin{array}{l}\text { How would you assess } \\
\text { combining motherhood } \\
\text { with employment }\end{array}$ & Frequency & Percentage \\
\hline Challenging & 104 & 65.0 \\
\hline Very interesting & 56 & 35.0 \\
\hline Total & 160 & 100.0 \\
\hline Why is it interesting? & Frequency & Percentage \\
\hline $\begin{array}{l}\text { Children are God's } \\
\text { blessing }\end{array}$ & 65 & 62.5 \\
\hline I have assistants & 39 & 37.5 \\
\hline Total & 104 & 100.0 \\
\hline
\end{tabular}




\begin{tabular}{|c|c|c|}
\hline $\begin{array}{l}\text { Why do you find it } \\
\text { challenging? }\end{array}$ & Frequency & Percentage \\
\hline $\begin{array}{l}\text { The nature of my work is } \\
\text { tasking }\end{array}$ & 26 & 46.4 \\
\hline Lack of assistants & 14 & 25.0 \\
\hline I have a large family & 12 & 21.4 \\
\hline I cannot explain & 04 & 7.2 \\
\hline Total & 56 & 100.0 \\
\hline $\begin{array}{l}\text { What would you say is } \\
\text { the major challenge in } \\
\text { combining work and } \\
\text { motherhood? }\end{array}$ & Frequency & Percentage \\
\hline Closing hour & 55 & 34.3 \\
\hline Office demand & 30 & 18.8 \\
\hline Traffic stress after work & 42 & 26.3 \\
\hline $\begin{array}{l}\text { Domestic duties after } \\
\text { work }\end{array}$ & 33 & 20.6 \\
\hline Total & 160 & 100.0 \\
\hline $\begin{array}{l}\text { Do you have crèche close } \\
\text { to your work place? }\end{array}$ & Frequency & Percentage \\
\hline Yes & 140 & 87.5 \\
\hline No & 20 & 12.5 \\
\hline Total & 160 & 100.0 \\
\hline Do you patronize it? & Frequency & Percentage \\
\hline Yes & 116 & 72.5 \\
\hline No & 44 & 27.5 \\
\hline Total & 160 & 100.0 \\
\hline $\begin{array}{l}\text { Have the facilities being } \\
\text { of help? }\end{array}$ & Frequency & Percentage \\
\hline Yes & 108 & 67.5 \\
\hline No & 52 & 32.5 \\
\hline Total & 160 & 100.0 \\
\hline If yes why? & Frequency & Percentage \\
\hline Proximity & 48 & 44.4 \\
\hline My baby likes it & 37 & 34.3 \\
\hline Good facilities & 23 & 21.3 \\
\hline Total & 108 & 100.0 \\
\hline
\end{tabular}




\begin{tabular}{|l|l|l|}
\hline If no why not? & Frequency & Percentage \\
\hline I don't like the place & 26 & 50.0 \\
\hline It is expensive & 15 & 28.8 \\
\hline My child goes to school & 11 & 21.2 \\
\hline Total & 52 & 100.0 \\
\hline
\end{tabular}

From the table, 65.0 percent felt the task was challenging while the rest of the respondents (35.0 percent) claimed they found it very interesting. Buttressing on why they found it challenging, 46.4 percent of the respondents attributed it to the nature of their jobs; while 25.0 percent felt it was challenging because of lack of individuals to assist them. During the IDI sessions, some of the respondents had this to say regarding why they found motherhood and employment challenging:

I am the confidential secretary to my boss, he wants me to be around all the time, sometimes to go and pick up my kids after closing hour is difficult; I have to come to work very early and I may not leave until my boss is done for the day. My boss is a busy man; he doesn't close at the normal period and as his secretary you know what that means, am here till he leaves office (IDI, Female, Ado Ekiti)

Another respondent:

Actually I am not complaining, but not having somebody to assist me in taking care of the kids has been a major challenge; I am sure that it would have been easy assuming I have a house help or somebody to assist. My children are still very young, my husband doesn't work within the city, he comes home at fortnight, and sometimes at month end and am the only one taking care of the three of them... (IDI, Ado Ekiti).

Another respondent:

It is not easy... but combining the two are a necessity, you just have to do it... (IDI, Ado Ekiti).

The respondents (see Table 5) were asked to identify the major challenge facing them while combining work with motherhood; 34.3 percent attributed their main challenges to closing late from work; 18.8 percent claimed that the demands within the office was too tasking for them while 26.3 percent attributed it to the stress they face after the closing hour. 
The rest of the respondents (20.6percent) claimed that going home to tackle the domestic chores was their major challenge.

Table 5

Percentage Distribution of Respondents on the Challenges Faced and Implication on Mother and Child

\begin{tabular}{|l|l|l|}
\hline $\begin{array}{l}\text { Challenges Faced by } \\
\text { Mothers }\end{array}$ & Frequency & Percentage \\
\hline $\begin{array}{l}\text { Difficulty in combining } \\
\text { motherhood with job }\end{array}$ & 117 & 73.1 \\
\hline Financial problem & 43 & 26.9 \\
\hline Total & 160 & 100.0 \\
\hline $\begin{array}{l}\text { Perceived implications of } \\
\text { the challenges on child }\end{array}$ & Frequency & Percentage \\
\hline Malaria & 35 & 22.0 \\
\hline $\begin{array}{l}\text { Diarrhoea, loss of appetite } \\
\text { and weakness }\end{array}$ & 37 & 23.1 \\
\hline $\begin{array}{l}\text { Emotional and physical } \\
\text { discomfort }\end{array}$ & 88 & 54.9 \\
\hline Total & 160 & 100.0 \\
\hline $\begin{array}{l}\text { Perceived implication of } \\
\text { challenges on the mother }\end{array}$ & Frequency & Percentage \\
\hline $\begin{array}{l}\text { Loss of concentration at } \\
\text { work }\end{array}$ & 23 & 14.5 \\
\hline Stress and body weakness & 100 & 62.3 \\
\hline $\begin{array}{l}\text { Frequent disagreement } \\
\text { with spouse and } \\
\text { colleagues at work }\end{array}$ & 37 & 23.2 \\
\hline Total & 160 & 100.0 \\
\hline
\end{tabular}

Some of the responses of the respondents during the IDI are submitted below:

To me, working mothers having infants should be allowed to close early; in our workplace, you are allowed to close at $2 \mathrm{pm}$ for three months after resuming for maternity leave, but I feel this should be extended to 3 years. This will allow mothers to have time to take 


\section{Omotosho - Employment, Motherhood and Wellbeing}

care of their children till they are old enough to care for themselves, I think if this is addressed within the workplace, it will be a lot easier (IDI, Ado Ekiti).

Another respondent:

I am hopeful that I will get a car very soon; if this dream is realized, it will make my job easier as a mother, I would not have to go through the traffic stress, it will be easier to pack my children lunch while leaving in the morning and I think it will be a lot easier with a car... (IDI, Ado Ekiti).

Another respondent:

Everybody is always eager to leave at exactly $4 \mathrm{pm}$ (closing time), at this period, the whole place will be a mess due to traffic hold up, sometimes, I could spend up to 2 hours in the traffic... (IDI, Ado Ekiti).

Another respondent:

Getting home after work to cook and prepare for the next day is really an issue; it's like resuming for another work session after closing, even with house help, you will still need to supervise him/her to do the right thing.... It's not easy... (IDI, Ado Ekiti).

A number events are changing regarding the set up families across the globe (Ellison, Barker, Kulasuriya, 2009). For instance, parents in most societies across the globe now share the responsibilities of caring for their kids. This has made it easier for mothers to combine parenting and employment. However, data explaining how this is possible in Africa is however still lacking. From the data available in western world, a number of factors ranging from employment patterns, age of and number of the children within a family and ability to spend less hours have been argued to play key roles in determining the abilities of working mothers to easily combine parenting with their jobs

Further, majority of the respondents (87.5 percent) had crèche around their workplace and 72.5 percent of them patronized the place. The few respondents who were not patronizing the place attributed it to the fact that they do not like the place and that the crèche is expensive. While little information is available regarding the state of crèche facilities for nursing mothers within the workplace, what is obvious is that a quantum leap has been taken in this regard. A number of crèche facilities are emerging across workplaces, though this may not be adequate; apart from this, the 
traditional methods where relations namely grandmothers, and older siblings take care of their younger are still in place, though it has been criticized as having a negative effect on the child (Engle 1991; Leslie and Paolisso, 1989). Notwithstanding, these traditional methods still play key roles in providing care for the child.

This segment (see Table 5) describes the percentage distribution of respondents as regards the challenges they face and the perceived impact on them and their children. Findings revealed that about 73.1 percent claimed the challenges include how to combine work with mother hood while 26.9 percent attributed it to financial challenges in meeting their needs and that of their children. Their argument was that they engage in paid employment based on the need to get more money to take care of themselves and their children. Regarding the implications on them and their children, respondents claimed that their children experience diarrhoea and malaria (22.2 percent), loss of appetite and weakness (23.1 percent) while 54.9 percent claimed that their children experience some emotional discomfort like refusal to stay with child attendants. However, 23.0 percent claimed that their children did not show any negative symptoms as a result of their jobs. On the part of the mothers, 62.3 percent claimed that their major challenge as a result of combining work and motherhood includes stress and in ability to focus on their work. Further, 23.2 percent claimed they had frequent disagreements with their spouses over work related issues. Some of the IDI responses are captured below to corroborate this analysis:

My main issue with combining work and motherhood is the stress of crèche, some of the handlers of the centres may not be professional enough, they keep changing handlers which to me is not good for the children; by the time my child is getting used to a care giver, another one is brought, this has always made it difficult for my child to stay. I would need to pacify her before she could stay, even after leaving I would be summoned that my child needs my attention because she is always upset because of the environment. On the long run, I find it difficult to concentrate because sometimes I would be wondering if my baby has not started crying... (IDI, Ado Ekiti).

Another respondent gave her remarks:

My husband feels I should quit salaried job. He feels I need more time to stay with the kids. But if I would want to do that, where would the money come from? Sometimes this generates argument 
between me and my husband. Though I plan to leave as soon as we are able to gather enough money to start a business... (IDI, Ado Ekiti).

Several empirical works have explained the synergy between these variables (Blau and Grossberg, 1992; Ermisch and Francesconi, 2005; Berna, 2008). However, each scholar has taken different stands from neutral to extreme sides. This has made it a bit cumbersome to analyze. A number of factors have to be taken into consideration before a definite statement can be made regarding the impact mother's job on child. For instance, Mancini and Pasqua (2012) suggested that the number of time spent on children must be taken into consideration while Hsin, (2009) laid emphasis on the level of education of the mother as an important variable to consider.

The respondents (see Table 6) were asked on how they coped with motherhood and employment; respondents had different means by which they achieved this.

Table 6

Percentage Distribution of the Coping Strategies of the Respondents

\begin{tabular}{|l|l|l|}
\hline $\begin{array}{l}\text { How do you cope combining } \\
\text { motherhood with your job? }\end{array}$ & Frequency & Percentage \\
\hline Through child spacing & 12 & 7.5 \\
\hline $\begin{array}{l}\text { I ask for the help of nannies to } \\
\text { assist }\end{array}$ & 28 & 17.5 \\
\hline $\begin{array}{l}\text { My husband and myself both } \\
\text { carry the responsibility }\end{array}$ & 28 & 17.5 \\
\hline $\begin{array}{l}\text { I drop my child with crèche } \\
\text { before going to work }\end{array}$ & 40 & 25.0 \\
\hline $\begin{array}{l}\text { Mothers enjoy free hands in my } \\
\text { work place }\end{array}$ & 52 & 32.5 \\
\hline Total & 160 & 100.0 \\
\hline
\end{tabular}




\begin{tabular}{|l|l|l|}
\hline $\begin{array}{l}\text { What do you think can } \\
\text { alleviate the stress of } \\
\text { combining work and } \\
\text { motherhood }\end{array}$ & Frequency & Percentage \\
\hline Reduce working hour & 39 & 24.3 \\
\hline Special allowance & 78 & 48.8 \\
\hline Increase maternity leave periods & 43 & 26.9 \\
\hline Total & 160 & 100.0 \\
\hline
\end{tabular}

For instance 7.7 percent of the respondents claimed they spaced the birth of their children; 17.5 percent claimed they asked for the assistance of domestic help. Other respondents (17.5 percent) claimed that the assistance rendered by their spouses made it easy to survive; further, 25.0 percent argued that they relied on the facilities provided by day care centres while 48.8 percent argued that the working condition in their workplaces were not arduous. IDI conducted further shed light on the strategies adopted by the mothers to cope with challenges associated with motherhood and employment. Some of their comments are highlighted below:

It is easier to manage work and motherhood unlike what it used to be when I had my first baby. At that time, we didn't have a crèche around my office area but now we do. It was easier to visit the place and nurse my child when he was suckling and now that he has stopped, I still pay him visits in between office hours. At closing hour, I pick our second baby in the crèche while my husband brings our first son home from school... (IDI, Ado Ekiti).

Another respondent:

I think the work stress in this unit is very minimal; thus, you are allowed to check on your child at the day care centre as often as you want to. So my job demands doesn't have adverse effect on my role as a mother... (IDI, Ado Ekiti).

Another respondent:

We (myself and the rest of the family) all leave home at the same time and return at the same time in our car..., my office is closer to my house, I am usually the first person my husband drops off in the morning, so I just drop my baby in the crèche while my husband drops our other children in the school (they attend the same school). He follows the same routine in the afternoon, and to me 
this make it easier rather than me doing all the work. (IDI, Ado Ekiti).

Available evidences have always suggested that balancing work responsibilities and parenting is often a challenge (Parker and Wang, 2013), however, the outcome of such balancing exercise often reveals that parents are happy with the outcome of their efforts.

The respondents were also asked on how they think the stress of combining motherhood and employment be reduced; 24 . percent of the respondents suggested that office hours should be reduced; 48.8 percent of the respondents opined that there must be special allowances paid to working mothers to compensate for the stress while the remaining 26.9 percent felt that the present three months' maternity leave given to women after child birth be increased. Some of the IDI responses buttressing these arguments are captured below:

Mothers having toddlers should be allowed to close early; this will enable them have ample time to take care of the kids and also prepare for work. Apart from this, they should also give them more maternity leave periods (IDI, Ado Ekiti);

Another respondent gave her remarks:

We are told that in developed countries, there are special allowances for nursing mothers. They should introduce that in our country as well. Though this cannot really alleviate the stress, but it will go a long way in mitigating the effects as mothers will have enough money to secure the services of domestic help and further take care of the children.

\section{Test of hypotheses}

This section presents some findings regarding the statistical relationship among the variables tested for the study.

The first hypothesis states that there is a significant relationship between age and finding parenting and employment easy to cope with. As regards the chi-square test of association between age and finding parenting and employment easy to cope with, data revealed that there was a significant association between the variables (.000). By implication, age could play an important role in determining how easy it would be in combining motherhood and employment. Younger couples who have not 
had more than one child appears to find it easy to cope with the demands of motherhood and employment for a number of reasons. First they have just entered the business of procreation and thus it is fascinating for them rather than couples with more children. This may however not suggest that in most instances older women may find it more difficult in most cases than the young women. Older women with infants may find it easier to cope with work if they have older children that may assist them in taking care of their infants. This of course is not an alien culture in Africa where older children are expected to take care of their younger ones.

Data on significant relationship between marital status and finding parenting and employment easy revealed that statistically there was no significant association between both variables (.012). By implication, marital status may not have strong implications on respondents' ability to juggle between work and motherhood. IDI conducted further attests to this,

I live with my parents, so my mom takes care of my daughter when am away to work, sometimes the girl doesn't even miss me because she enjoys the company of my mom more than myself. Taking care of the kid is not an issue to me at all. My mother does it all. (IDI, Ado Ekiti).

Another respondent:

Combining my roles as a mother and a worker is not an easy task. I have about 3 of my husband's family members leaving with us- my mother-in-law and two others. To cater for these set of people including my two children plus my husband is really a big deal. Yet, I will still be expected to report early for work the following day. (IDI, Ado Ekiti).

A number of factors intervene in determining the ability of mothers to effectively combine parenting and work. For instance, it has been widely argued within literature that single mothers often find it difficult to combine work and parenting, yet other works have also opined that a number of factors like income of the single mother equally play important roles as well (Alberda, 2009). From this finding, the roles of significant others namely family members and friends may equally make the job easier for single mothers. The general assumption regarding married mothers is that they enjoy maximum support from family members but this may not be so in all situations. Traditionally, external influence and supports are minimal for 


\section{Omotosho - Employment, Motherhood and Wellbeing}

married mothers and they may have to depend on their husbands and very close relations for support which are usually time based.

Findings on the statistical relationship between respondents who give in their best to work often find motherhood and employment an easy task shows that a significant relationship exists between the variables (0.002). By implication those who give in their best in their work settings are likely to give in their best to motherhood. While this may be hard to explain, this phenomenon may suggest attitudinal issues as a strong determinant for success. This is because women in employment tend to perform in one aspect to the detriment of the other (Carr, Ash, Friedman, Scaramucci, Barnett, Szalacha, Palepu, Moskowitz, 1998). Studies have however affirmed a strong relationship between work preferences and attitudes (Hakim, 2001); however, studies have equally added that attitudes towards work are a combination of many factors ranging from educational attainment, their ethnic and social background, their employment record and age all play important roles in attitudes (Kangas and Rostgaard, 2007). Studies examining the linkage between success in work preferences and motherhood are however lacking.

\section{Conclusion and Recommendation}

This study explores how working mothers within public organisations juggles between parenting and employment. A number of issues became clear, first, combining work and motherhood is a difficult process for mothers. This challenge may continue considering the persistent demand of employers for effectiveness and productivity. Children and mothers may also continue to experience different kinds of challenges due to the demands in the workplace. Second further studies exploring issues surrounding working mothers within work settings in developing countries and especially in Africa is still needed. Data explaining the realities within these spaces are still limited to developed nations. The study recommends the need for both stakeholders (policy makers and employers of labour) to adopt means of ensuring working mothers are at their optimum capacities for parenting and career. 


\section{References}

Albelda, R. (2009). Why it's harder (and different) for single mothers: Gender, motherhood, labor markets and public work supports. Center for Social Policy and Department of Economics University of Massachusetts Boston January

Ammaniti, M., Ambruzzi M.; Lucarelli, L; Cimino, L; \& Linpio F.(2004). Malnutrition and dysfunctional mother-child feeding interaction: Clinical assessment and research implications. Journal of the American college of Nutrition Vol 23, No3, pp 259-271.

Barnett, R. C., Marshall, N. L., \& Sayer, A. (1992). Positive-spillover effects from job to home: A closer look. Women and Health, 19(2/3), 13-41.

Basu, A. (1992). Women economic roles and child health: An overview Presented at the International Conference on Population and Development [ICPD], Expert Group Meeting on Population and Women, Gaborone, Botswana, June 22-26. 17 p.

Berna, R. (2008). The Effect of Maternal Employment and Child Care on Children's Cognitive Development International Economic Review Vol. 49 , No.

4 ,

November https://economia.uniandes.edu.co/files/profesores/raquel_bern al/docs/IER_maternal_employment_print_version_4.pdf

Blau, F. D. \& Grossberg, A. J, (1992). "Maternal Labor Supply and Children's Cognitive Development," The Review of Economics and Statistics, MIT Press, vol. 74(3), pages 474-481, August.

Bolzendahl C., \& Meyers, D.J. (2004). Feminist attitudes and support for gender equality: Opinion change in women and men, 1974-1998. Social Forces 83(2):759-790.

Budig, M. \& England, P. (2001). The wage penalty for motherhood. American Sociological Review. 66, 204-225.

Carr P.L., Ash A.S., Friedman R.H., Scaramucci A., Barnett R.C, Szalacha L., Palepu A., \& Moskowitz M.A. (1998). Relation of family responsibilities and gender to the productivity and career satisfaction of medical faculty. Ann Intern Med., 129 (7): 532-538.

Charles N \& Harris C. (2007). Continuity and change in work-life balance choices. British Journal of Sociology 58 (2): 277-295. 
Chete, L.N., Adeoti, J.O., Adeyinka, F.M., \& Ogundele, O. (2014). Industrial development and growth in Nigeria: Lessons and challenges. Learning to Complete Working Paper (2114) No 8 http://www.brookings.edu/ /media/Research/Files/Papers/2014/11/learni ng-to-compete/L2C_WP8_Chete-et-al.pdf?la=en.

Correll, S., Bernard, S., \& Paik, I. (2007). Getting a Job: Is there a motherhood penalty? American Journal of Sociology. 112, 1297-1338.

Ellison, A., Barker, A., \& Kulasuriya, A.(2009). Work and care: a study of modern parents Equality and Human Rights Commission Research Report Series www.equalityhumanrights.com. Accessed on 21 January, 2016.

Engle, P. L. (1991). Maternal work and child-care strategies in peri-urban Guatemala: Nutritional effects. Child Development 62 (1991):954-965.

Ermisch, J. \& Nicoletti, C. (2005). "Intergenerational earnings mobility: Changes across cohorts in Britain" ISER Working Paper 19 https://www.iser.essex.ac.uk/files/iser working papers/2005-19.pdf

Falzon, J.(2007). The Role of the Mother in the Child's Development www.childabuse.suite101.com. Accessed on 13th Accessed on 13th may, 2015.

Gungor, G. \& Biernat, M. (2009). Gender bias or motherhood disadvantage? Judgments of blue collar mothers and fathers in the workplace. Sex Roles, 60, 232-246.

Hakim, C. (2001). Work-Lifestyle Choices in the Twenty-First Century: Preference Theory. Oxford: Oxford University Press.

Heilman, M. E. \& Okimoto, T. G. (2008). Motherhood: A potential source of bias in employment decisions. Journal of Applied Psychology, 93(1), 189-198.

Hein, C.; Cassirer, N. (2010). Workplace solutions for childcare Geneva, International Labour Office,

Hoffman, L.W. (1963). The effect of maternal employment on children The Employed Mother in America. Nye and Hoffman (eds) www.dowiley.com pp1469-7610.

Hsin, A. (2009). "Parent's Time with Children: Does Time Matter for Children's Cognitive Achievement?" Social Indicators Research, 93(1): $123-126$ 
International Labour Office (2010). World of work report 2010: from one crisis to the next? / International Labour Office. http://www.ilo.org/public/portugue/region/eurpro/lisbon/pdf/worl dwork_2010.pdf

Joekes, S. (1989). Women's work and social support for child care in the Third World in J. Leslie and M. Paolisso (Eds.), Women, Work, and Child Welfare in the Third World, Boulder, CO: Westview Press.

Kaiser Family Foundation. (2003). Women, work, and family health: A balancing act issue brief. April www.kff.org..

Kan, M.Y. (2007). Work orientation and wives' employment careers: An evaluation of Hakim's preference theory. Work and Occupations 34 (4): 430-462.

Kangas O., \& Rostgaard, T. (2007) Preferences or institutions? Wo.rk family life opportunities in seven European countries, Journal of European Social Policy 17 (3): 240-256.

Leslie, J., \& Paolisso, M. (1989). Women, work and child welfare in the Third World. AAAS Selected Symposia Series, Colorado: (Westview Press).

Leslie, J. (1989). Woman's Work and Child Nutrition in the Third World in J. Leslie and M. Paolisso (Eds.), Women, Work, and Child Welfare in the Third World, Boulder, CO: (Westview Press).

Mancini, A.L., \& Pasqua, S. (2012). "Asymmetries and Interdependencies in Time Use Between Italian Parents". Applied Economics, 44(32), 41534171

Omoruyi O. (1994). et al (Eds) Democratization in Africa- Nigeria perspectives. Vol.2 Benin city- Centre for Democratic Studies. P. 101.

Orr, J. (1997). Working mothers: The double shift Socialist Review. (Issue 206,).

Parker, K., \& Wang, W. (2013). Roles of Moms and Dads Converge as They Balance Work and Family Modern Parenthood March 14. Pew Research Center http://www.pewsocialtrends.org/2013/03/14/modern-parenthoodroles-of-moms-and-dads-converge-as-they-balance-work-and-family/ accessed on 15th February, 2016.

Ridgeway, C. \& Correll, S. (2004). Motherhood as a status characteristic. The Journal of Social issues, (60), 683-700. 
1287 Omotosho - Employment, Motherhood and Wellbeing

Sun news online. (2013). Gender policies: The odds against women in Nigeria http://sunnewsonline.com/new/gender-policies-the-odds-againstwomen-in-nigeria/ accessed on 13th May, 2015.

Williams, C.L. (1992). The glass escalator: hidden advantages for men in the 'female' professions. Social Problems. (Vol 39, No 3, August). Pp 253267.

Babatunde JoshuaOmotosho, senior lecturer

Contact address:

Federal University Oye-Ekiti. Department of Sociology, P.M.B 373, Oye-Ekiti, Ekiti State, NIGERIA.

E-mail address: babatundeomotosho@gmail.com 


\section{Géneros}

Multidisciplinary Journal of Gendel: Studies
Hipatia Press

www.hipatiapress.com

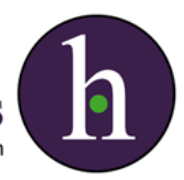

Instructions for authors, subscriptions and further details:

http://generos.hipatiapress.com

\section{We believe you. Survivors of Campus Sexual Assault Speak Out.}

Ana Vidu ${ }^{1}$

1) Universitat de Barcelona. Spain

Date of publication: February $25^{\text {th }}, 2017$

Edition period: February 2017 - June 2017

To cite this article: Vidu, A. (2017). We believe you. Survivors of Campus Sexual Assault Speak Out. [Review of the book]. Multidisciplinary Journal of Gender Studies, 6(1), 1288-1289. doi: 10.4471/generos.2017.2597

To link this article: http://dx.doi.org/10.4471/generos.2017.2597 
The terms and conditions of use are related to the Open Journal System and to Creative Commons Attribution License (CC-BY). 

GÉNEROS-Multidisciplinary Journal of Gender Studies Vol. 6 No. 1 February 2017 pp. 1288-1289

\section{Review}

Clark, A. \& Pino, A. (2016). We believe you. Survivors of Campus Sexual Assault Speak Out. New York: Holt Paperbacks. ISBN: 9781627795333

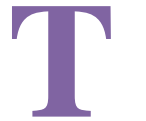

This book is describing the problematic reality of the campus sexual violence in a very special way, through the voices of thirtysix survivors who spoke out against the issue and started to lead this struggle across the United States. The authors, Andrea Pino and Annie Clark are themselves brave survivors of sexual violence and leaders of Title IX complaints at their universities and also activists. Their stories contributed to not only create awareness about the issue, but also to mobilize student movements at several universities across their country.

"We believe you" is written by survivors and for survivors; very much focused on how the harassment is taking place, why it is so deeply happening in the university context; and especially the book pretends to emphasize the consequences that sexual violence manifest for survivors. The book is structured into five parts, besides the initial introduction and the final part of rights and resources. From the introduction, the story of Annie and Andrea got to impact the readers. The first part, Before, describe the social context where the victims came from, their personal situations, especially with the aim of making others to understand how hard is to suffer from sexual violence, not only for the person itself but also for the context in which she or he are developing. In this way, their journeys of healing and survivorhood make totally sense, mainly because the authors emphasize the lack of social positioning against this issue as well as the perfect image that society use to have regarding universities. 
In the second part of the book, the survivors who gave their testimony for this explained how it happened, referring to the situation of their harassment. The survivors who described their background in the first part are incorporating here the sexual violence their suffered into their life story. The details and the deep way in which situations of rape and violence are described in this part, make the reader to better understand these disastrous episodes which may lead to create connection with this reality. In the third part of the book trauma and betrayal the victims talk about their experiences of dealing with the abuse in their everyday contexts. It is interesting to highlight the other people tolerance or lack of response, in front of this problem. Most of the university members and part of the society tend to not take any stand, or even worst to blame the victim for the situations that happened to them. However, other people's bravery helped the victims to go forward and to deal with the worst of the quotidian consequences as a result of what they suffered. Solidarity and peer support are key in this sense.

The fourth part healing and everyday activism starts with a description of concrete situations related to the condition of being a victim, such as losing interest in school, nightmares, fear and emotions. Sharing the experiences of trauma helped these survivors not to feel alone, to get stronger together, and also to realize that they were already activists. Their lives changed at that moment, feeling ready to contribute to the commitment for doing what they call "a culture shift" changing the dominant culture already prevailing in society, which for instance make some people to get more upset about a football losing than a sexual assault. The fifth part of the book, declarations of independence, the brave survivors who broke their silence along this book show how, in fact, this act is itself positive, for them and for the world. Their activism is based on previous work done on the issue and their stories have already influenced the future actions to be done. Supporting survivors is a revolutionary act and crucial for them to keep forward. Finally, the book ends by presenting some rights and resources for the victims. Listen, support, believe are key concepts to apply for each survivor' story, overcoming the victim blaming and standing always on the victim side, with no doubts. 